\title{
Melatonin and the control of intraocular pressure
}

\author{
Hanan Awad Alkozi ${ }^{\mathrm{a}, 1,3}$, Gemma Navarro ${ }^{\mathrm{b}, \mathrm{c}, 1,3}$, Rafael Franco ${ }^{\mathrm{b}, \mathrm{d}, 1,3, *}$, Jesus Pintor ${ }^{\mathrm{a}, \mathrm{e}, 1,2,3, * *}$ \\ ${ }^{a}$ Department of Biochemistry and Molecular Biology, Faculty of Optics and Optometry, University Complutense of Madrid, Madrid, Spain

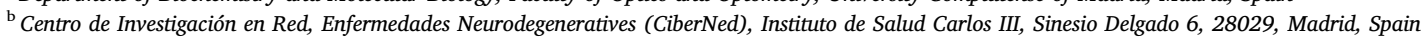 \\ ${ }^{\mathrm{c}}$ Department of Biochemistry and Physiology, School of Pharmacy and Food Sciences, Universitat de Barcelona, Avda. Juan XXIII, 27, 08027, Barcelona, Spain \\ ${ }^{\mathrm{d}}$ Department of Biochemistry and Molecular Biomedicine, School of Biology, Universitat de Barcelona, Diagonal 643, 08028, Barcelona, Barcelona, Spain \\ ${ }^{\mathrm{e}}$ Real Academia Nacional de Farmacia, Calle Farmacia 11, 28004, Madrid, Spain
}

\section{A R T I C L E I N F O}

\section{Keywords:}

Melatonin

Aqueous humor

Intraocular pressure

Glaucoma

Receptor heteromerization

\begin{abstract}
A B S T R A C T
Melatonin is not only synthesized by the pineal gland but by several ocular structures. This natural indoleamine is of great importance for regulating several eye processes, among which pressure homeostasis is included. Glaucoma, the most prevalent eye disease, also known as the silent thief of vision, is a multifactorial pathology that is associated to age and, often, to intraocular hypertension (IOP). Indeed IOP is the only modifiable risk factor and as such medications are available to control it; however, novel medications are sought to minimize undesirable side effects. Melatonin and analogues decrease IOP in both normotensive and hypertensive eyes. Melatonin activates its cognate membrane receptors, $\mathrm{MT}_{1}$ and $\mathrm{MT}_{2}$, which are present in numerous ocular tissues, including the aqueous-humor-producing ciliary processes. Melatonin receptors belong to the superfamily of G-protein-coupled receptors and their activation would lead to different signalling pathways depending on the tissue. This review describes the molecular mechanisms underlying differential functionalities that are attributed to melatonin receptors. Accordingly, the current work highlights the important role of melatonin and its analogues in the healthy and in the glaucomatous eyes, with special attention to the control of intraocular pressure.
\end{abstract}

\section{Melatonin discovery and synthesis}

\subsection{Introduction}

In the search for substances to treat vitiligo, the dermatologist Aaron Lerner discovered in late 50s a molecule produced by the bovine pineal gland that was able to lighten amphibian melanocytes by causing the aggregation of melanin near the nucleus of the cells (Lerner and Case, 1959). Lerner and colleagues focused their research on the active substance from pineal gland which was first named as melatonin and further identified as N-acetyl-5-methoxytryptamine, an indoleamine (Lerner et al., 1960). Melatonin is composed of the prefix "mela", which refers to melanin, and the suffix "tonin" because serotonin is its precursor (Reiter et al., 2014a). Although the main aim of Lerner's and colleagues research was the therapy of skin ailments, the discovery of melatonin paved the way to demonstrate the involvement of the indoleamine in regulation of a wide variety of physiological processes. Lerner and his team were the first to notice that melatonin was able to induce sleep (Lerner and Nordlund, 1978), hence attracting the attention of scientists in the field of circadian rhythms.

Melatonin metabolism in the pineal gland starts by hydroxylation of tryptophan uptaken by pinealocytes. Hydroxylated tryptophan becomes decarboxylated by the L-aromatic amino acid decarboxylase to form, serotonin, the biogenic amine (Axelrod, 1974). The first rate-limiting enzyme in most reported studies of melatonin synthesis, named arylalkymine N-acetyltransferase (AANAT), uses a small percentage of the produced serotonin (around 5-25\%) and catalyzes the transfer of the acetyl group from acetyl-CoA to serotonin. N-acetyl-serotonin (NAS) is finally converted to melatonin, by hydroxyindole-O-methyltransferase (HIOMT), a cytosolic protein which constitutes $2-4 \%$ of total soluble

\footnotetext{
${ }^{*}$ Corresponding author. Department of Biochemistry and Molecular Biomedicine, School of Biology, Universitat de Barcelona, Diagonal 643, 08028, Barcelona, Barcelona, Spain.

** Corresponding author. Department of Biochemistry and Molecular Biology, Faculty of Optics and Optometry, University Complutense of Madrid, Arcos de Jalón, 118, 28037, Madrid, Spain.

E-mail addresses: rfranco@ub.edu (R. Franco), Jpintor@ucm.es (J. Pintor).

${ }^{1}$ Equal contribution.

${ }^{2}$ In memoriam.

${ }^{3}$ Percentage of work contributed by each author in the production of the manuscript is as follows: Hanan Awad Alkozi 25\%; Gemma Navarro 25\%; Rafael Franco 25\%; Jesus Pintor 25\%.
} 
proteins in the pineal gland. The enzyme catalyzes the O-methylation of NAS using S-adenosyl methionine as a single carbon donor and its involvement in melatonin synthesis was observed in the rat pineal gland (Liu and Borjigin, 2005).

The process of melatonin synthesis is driven by circadian rhythms, reaching a concentration peak at night (Pevet, 2002, 2014; Tosini and Fukuhara, 2003; Zawilska et al., 2002). In extrapineal structures, melatonin synthesis does not follow circadian rhythms; in addition it has been reported that mitochondria may produce the compound (Suofu et al., 2017). The increase of melatonin synthesis at night is stimulated by signals originated at neurons of the suprachiasmatic nucleus (SCN). Via the eyes, these neurons receive information about the time of the day and send inputs through the paraventricular nucleus (PVN) to the spinal cord and the superior cervical ganglia (SCG) of the sympathetic nervous system. Such adrenergic fibers are located adjacent to pinealocytes (Moore and Klein, 1974), in which norepinephrine receptors become activated. In fact, norepinephrine may bind to $\alpha$ - and $\beta$-adrenergic receptors present in the cell surface of pinealocytes and each receptor mediates the regulation of melatonin synthesizing-enzyme expression. $\beta$-adrenoceptor activation stimulates a heterotrimeric Gs protein that activates adenylyl cyclase to produce cAMP from ATP. cAMP, the main second messenger in mammalian cells, activates the protein kinase A pathway that in turns enhances the expression of AANAT and/or boosts its catalytic activity (Klein et al., 1992, 1997; Minneman and Iversen, 1976). In contrast, the stimulation of $\alpha$-adrenoceptors activates a Gq protein that is linked to the phospholipase $\mathrm{C}$ (PLC)-phosphatidylinositol-protein kinase C (PKC) cascade (Fig. 1). In such pathway the main second messenger is calcium ion, whose role in the expression of melatonin-metabolizing effects is not known. However, PKC may act on adenylate cyclase to enhance cAMP levels, AANAT activity and melatonin synthesis (Ho et al., 1988). Accordingly, pineal AANAT activity may be regulated by neurotransmitters that act via cAMP-related mechanisms (Hardeland, 2008).

Melatonin levels rise at night due to release from the pineal gland to the cerebrospinal fluid as well as to the blood stream (Reiter et al., 2014b; Tan et al., 2016) (Fig. 1). Although the first hypothesis pointed to melatonin being uniquely synthesized by the pineal gland, melatonin-synthesizing enzymes were detected in cells other than those in the pineal gland (Acuña-Castroviejo et al., 2014). Of particular interest for this review is the presence of melatonin in the eye, the underlying mechanisms and its specific function(s) in the physiology of the eye.

\subsection{Sources of melatonin in the eye}

After its identification in the pineal gland, synthesis of melatonin was detected in different regions of the brain, among others in the hypothalamus, the habenula (Axelrod et al., 1961) and the cerebellum (Bubenik et al., 1974). The retina was one of the first structures where the melatonin synthesis was identified (Huang et al., 2013; Nagle et al., 1973). The finding was confirmed by detecting melatonin-synthesizing enzymes even after pinealectomy. Interestingly, Bubenik and collaborators showed that $\mathrm{N}$-acetylindolealkylamines in the retina do not come from axons coming from neurons in the optic nerve (Bubenik et al., 1974). The relevance of these results was questioned due to the lack of HIOMT in the human retina (Bernard et al., 1995). However, melatonin is indeed produced in different cell types of the human eye. As an example Zmijewski et al. (2009) reported that the indolamine was produced by human retinal pigment epithelial ARPE-19 cells; more examples are provided below (Zmijewski et al., 2009).

An interesting approach to the in vitro study of melatonin synthesis is to provide the melatonin precursor, tryptophan, by continuous perfusion. One experiment done in late 90s showed that addition of tryptophan to the harderian gland, a juxtaorbital gland existing in some vertebrates, increases melatonin release up to 2.5 -fold higher than melatonin released from untreated samples (Djeridane et al., 1998). Experiments in the same laboratory aiming at investigating melatonin production showed that unlike the pineal gland, melatonin levels in the harderian gland do not change according to the time of the day (Djeridane and Touitou, 2001).

Another ocular structure where melatonin may be synthesized is in the crystalline lens. Melatonin and its precursors were detected in rabbit lenses, together with the activity of both synthesizing enzymes, AANAT and HIOMT. Moreover, melatonin and AANAT followed a circadian rhythm similar to that in the pineal gland, being significantly higher during the night in comparison to daylight (Abe et al., 1999).

Melatonin has been also found in the iris and ciliary body. This was a likely hypothesis due to melatonin regulation of IOP (see below), due to the existence of diurnal changes in the intraocular pressure (IOP), and due to ciliary epithelium sharing the same embryonic origin than the pineal gland and the retina. In fact, Martin and collaborators found

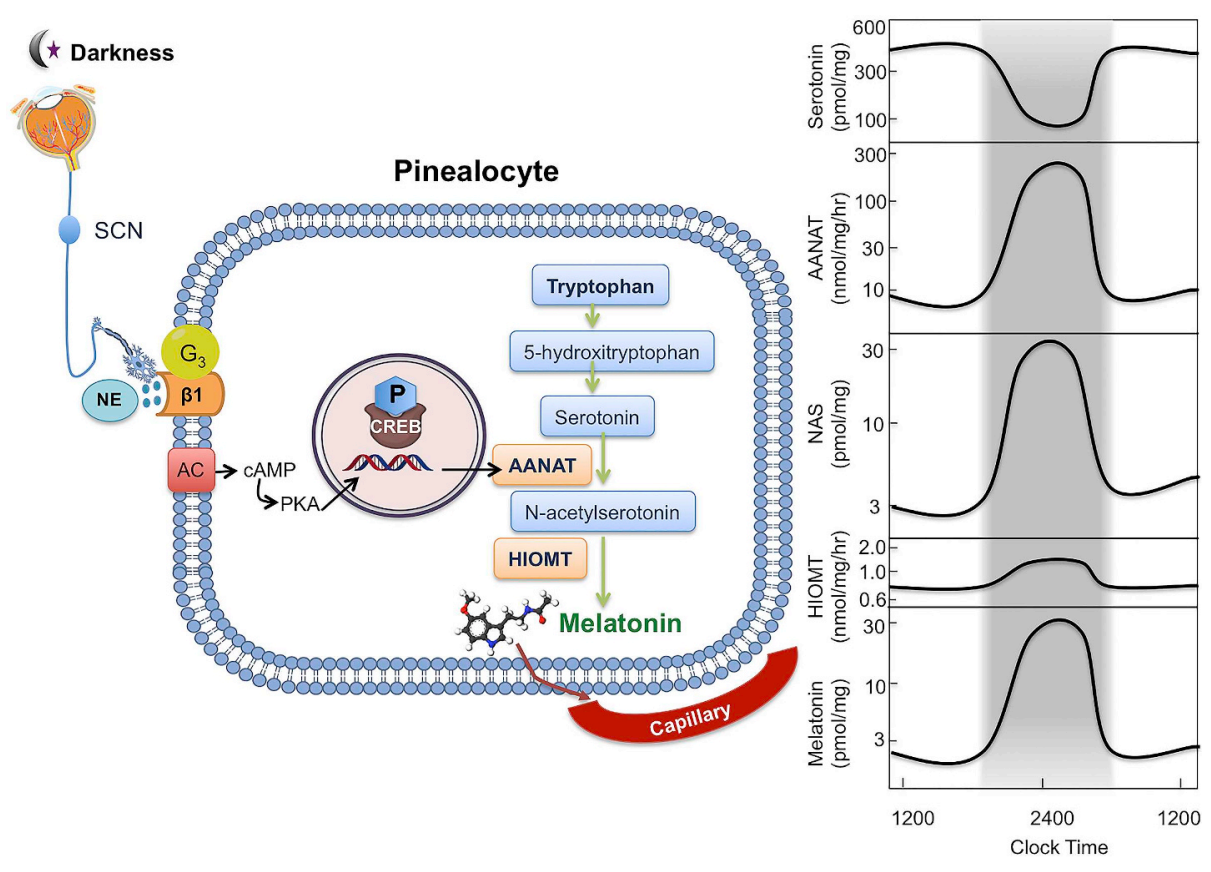

Fig. 1. Scheme of melatonin synthesis in the pineal gland (left) and of daily rhythmicity of indole levels (right). Serotonin levels are high during the day and decrease at night (grey) because of an increase in AANAT expression and activity due to signals of darkness coming from the eye through the Suprachiasmatic nucleus (SCN). AANAT transfers an acetyl group from acetyl CoA to 5-HT. The increase in AANAT activity results in an increase in the intracellular concentration of $\mathrm{N}$-acetyl serotonin, which is converted to melatonin by hydroxyindoleOmethyltransferase (modified from Klein, 1974). AANAT, arylalkylamine $\mathrm{N}$-acetyltransferase; AC, adenylyl cyclase; HIOMT, hydroxyindole-O-methyltransferase; cAMP, cyclic adenosine monophosphate; CREB, cAMP response element-binding protein; NAS, N-acetyl 5-methoxytryptamine; NE, norepinephrine; PKA, protein kinase A. 
serotonin, 6-hydroxymelatonin, and melatonin in the aqueous humor. Moreover, tryptophan, 5-hydroxytryptophan, serotonin, and 5-hydroxyindoeacetic were detected in ciliary bodies from quickly enucleated human eyes (Martin et al., 1992; Osborne, 1994). It was noteworthy to find that HIOMT activity was 50 times higher than that of AANAT, thus indicating that AANAT is the rate limiting enzyme in melatonin synthesis, an observation found also in the pineal gland (Klein, 2007; Martin et al., 1992).

\subsection{Melatonin receptors and signalling pathways}

Both melatonin production in numerous ocular structures and the higher concentration in the aqueous humor than in blood are evidence of relevant roles of the indoleamine in eye physiology and function. First of all, the action of melatonin seems mainly mediated by cell surface receptors, two of which $\mathrm{MT}_{1}$ and $\mathrm{MT}_{2}$, have been cloned and characterized (Morgan et al., 1989; Reppert, 1997; Reiter, 1991; Reppert et al., 1995; Reppert et al., 1994; Rivara et al., 2005). They have a relatively high degree of homology and are members of the superfamily of G-protein-coupled receptors (GPCRs). Occurrence of a putative $\mathrm{MT}_{3}$ receptor was reported on the basis of pharmacological evidence (Pintor et al., 2001). This activity was later attributed to quinone reductase 2 (QR2) (Mailliet et al., 2004), whose enzyme activity seems regulated by melatonin and by other endogenous (e.g. Nacetylserotonin) and exogenous compounds (e.g. resveratrol). These compounds act as negative allosteric modulators thus inhibiting the enzyme, which plays a role in reduction-oxidation (REDOX) mechanisms occurring between quinones, semiquinones, and hydroquinones. It is not clear whether QR2 has a relevant role in melatonin physiology although the data on the 5-MCA-NAT-QR2 interaction suggest that dopamine may indirectly mediate actions resulting from melatonin regulation of QR2 activity; in fact, melatonin inhibits dopamine release from amacrine cells (Lavoie et al., 2013; Sampaio Lde et al., 2014; Wiechmann and Sherry, 2013).

Apart from $\mathrm{MT}_{1}$ and $\mathrm{MT}_{2}$, the GPR50 orphan receptor shares $45 \%$ amino acid homology with melatonin receptors (Dufourny et al., 2008); nevertheless, melatonin does not bind to this receptor and the endogenous agonist has not been unambiguously identified (Reppert et al., 1996). A functional interaction between melatonin receptors and GPR50 has been reported. The orphan GPCR may directly interact with $\mathrm{MT}_{1}$ to inhibit the actions mediated by $\mathrm{MT}_{1}$ receptor (Levoye et al., 2006); the effect seems to be mediated by the C-terminal domain of GPR50. Deletion of the C-terminal tail of GPR50 led to abolishment of the inhibitory effect of GPR50 on $\mathrm{MT}_{1}$ but without affecting heterodimerization ( $\mathrm{Li}$ et al., 2013). The physiological meaning of such findings requires more experimental effort.

When individually expressed, $\mathrm{MT}_{1}$ and $\mathrm{MT}_{2}$ receptors couple to a heterotrimeric Gi protein. There are several members of $\mathrm{G}$ proteins, which are classified in four main categories (Zachariou et al., 2012). On the one hand, the Gs family stimulates adenylyl cyclase and leads to the increase of cAMP levels and subsequent protein kinase A (PKA) activation. On the other hand, members of the Gi family (which includes Gz, Go and Ggust) inhibit adenylyl cyclase to decrease cAMP levels and deactivate PKA but also regulate some $\mathrm{K}^{+}$, and voltage-gated $\mathrm{Ca}^{2+}$ channels. Gq proteins mediate phosphoinositide (PI) turnover and increase phospholipase $\mathrm{C}$ activity and cytosolic $\left[\mathrm{Ca}^{2+}\right]$. Finally, members of the G12 family regulate the activity of Rho-guanine nucleotide exchange factors.

Cognate proteins coupled to both melatonin receptors are of the $\mathrm{Gi}$ class (Fig. 2). Indeed, the activation of $\mathrm{MT}_{1}$ or $\mathrm{MT}_{2}$ receptors associates to reduction of forskolin-induced [cAMP] levels (Vanecek, 1998). By this canonical mechanism the PKA pathway is inactivated (von Gall et al., 2000). Depending on the experimental model, melatonin receptors may couple to other G proteins (Fig. 2) (Tslm et al., 1996). It is under question whether Gs activation may occur via $\mathrm{MT}_{1}$ in human prostate epithelial cells in which receptor-mediated antiproliferative

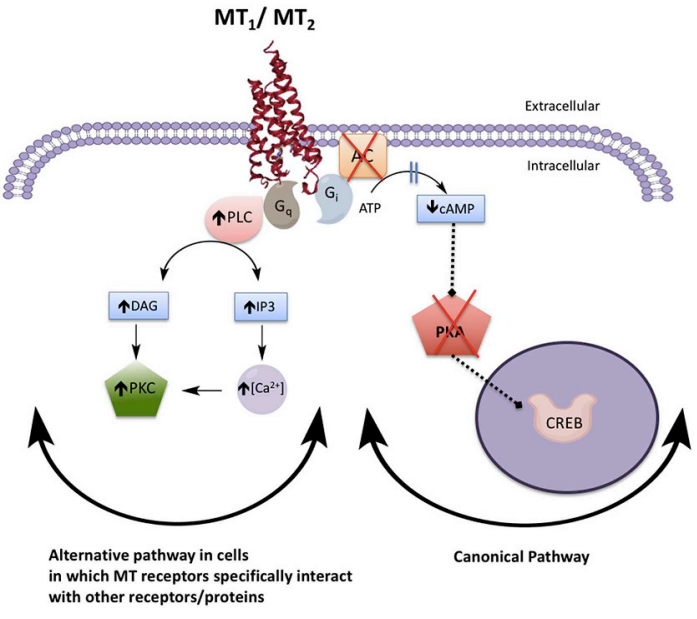

Fig. 2. Signalling events upon melatonin $\mathrm{MT}_{1}$ and $\mathrm{MT}_{2}$ receptor activation. Gi is the cognate protein to which receptors couple; accordingly, their activation reduces adenylyl cyclase (AC) activity, cAMP levels, cAMP-dependent protein kinase (PKA) activity and cAMP response-element-binding (CREB) is mostly in nonphosphorylated form (right). In circumstances in which there is Gq coupling, an alternative route due to overexpression in heterologous cells or interaction with other receptor/proteins happens. Gq engagement leads to phospholipase C (PLC) activation and cleavage of phosphatidylinositol diphosphate (PIP2) into inositol triphosphate (IP3) and diacylglycerol (DAG); these compounds in turn lead to increase cytosolic $\left[\mathrm{Ca}^{2+}\right]$ and protein kinase $\mathrm{C}$ (PKC) activity (left).

action of melatonin seemingly involves dual activation of $\mathrm{Gs}$ and $\mathrm{Gq}$ proteins (Shiu et al., 2010). In addition, $\mathrm{MT}_{1}$ and $\mathrm{MT}_{2}$ receptors in transfected COS-7 cells may couple to the G16 protein (Lai et al., 2002; Mody et al., 2000).

Involvement of calcium ion as second messenger has been suggested for a variety of GPCRs that are coupled to Gs or Gi. However the underlying mechanism of intracellular calcium mobilization is controversial. A direct pathway would be mediated by Gq-coupled melatonin receptors. Activation of $\mathrm{Gq}$ has been demonstrated for the $\mathrm{MT}_{1}$ receptor-expressing gastrointestinal smooth muscle cells, with concomitant PLC activation and increases in cytosolic $\mathrm{Ca}^{2+}$ levels and PI hydrolysis (Ahmed et al., 2013). Activation of the $\mathrm{MT}_{1}$ receptor expressed in the HEK-293T cell line engages the phospholipase C- $\alpha$ (PLCa) pathway (Brydon et al., 1999), while activation of the $\mathrm{MT}_{2}$ receptor has been associated to changes in the activity of guanylate cyclase (Petit et al., 1998). In summary, the versatility of melatonin receptors in terms of signalling pathways may be partially related to a shift in the coupling to $G$ proteins. In vitro and in cell lines, melatonin receptors have the capacity to couple to multiple $\mathrm{G}$ proteins but identifying the interactions that are relevant from a physiological point of view will require further experimental effort and insights into melatonin receptor-G protein structures. The most plausible hypothesis is that Gi is the cognate protein of melatonin receptors (as IUPHAR recognizes) and that coupling to other G proteins may occur "artificially" in heterologous expression systems or be physiological when melatonin receptors interact with other receptors/proteins (see below for examples).

\subsection{Wide expression of melatonin receptors in the eye}

Melatonin receptors are not only expressed in the CNS (for instance in the suprachiasmatic nucleus, pars tuberalis and visual areas) but in several ocular components. Accordingly, the role of melatonin receptors in eye physiology is of paramount importance. In addition, they mediate the night-day circadian rhythms in which eyes are at the centre stage (Iuvone et al., 2005; von Gall et al., 2002; Wiechmann and Summers, 2008; Zawilska, 1992).

In vertebrates, the neural retina consists of various neuronal cell 
types, among other photoreceptor, horizontal, bipolar, amacrine, interplexiform and ganglion cells. Melatonin participates in the circadian switching from cone to rod-driven functions (Cahill and Besharse, 1995). Hence it is anticipated that activation of melatonin receptors would result in an end-point in cone function to enhance rod functionality (Wiechmann and Sherry, 2013). Apart from their presence in the photoreceptor cells, melatonin receptors are expressed in the outer and inner parts of the retina (Wiechmann, 2003; Wiechmann and Sherry, 2012). In human, monkeys and rats, $\mathrm{MT}_{1}$ receptor is present in the horizontal cells in the inner and outer plexiform layer and in all amacrine cells (Fujieda et al., 1999, 2000; Scher et al., 2002), where it probably regulates the release of neurotransmitters such as acetylcholine (Fujieda et al., 1999). $\mathrm{MT}_{1}$ but not $\mathrm{MT}_{2}$ receptors are located in dopaminergic and GABAergic neurons where they regulate the release of GABA and dopamine from amacrine cells (Dubocovich, 1983). Melatonin also modulates, via melatonin receptors, dopamine release from retinal neurons (Dubocovich, 1983) and retinomotor movements, and mediates circadian outer segment disc shedding (Pierce and Besharse, 1985; White and Fisher, 1989).

Other ocular structures where the melatonin $\mathrm{MT}_{1}$ receptor was found are the choroid and the sclera. Although little is known about relevance for humans; evidence shows that $\mathrm{MT}_{1}$ receptors are expressed in chick choroid, which in turn present diurnal fluctuations in thickness, perhaps due to constriction of blood vessels (Nickla et al., 1998; Rada and Wiechmann, 2006). Furthermore, evidence of the presence of melatonin receptors in chick sclera suggested the participation of melatonin in ocular elongation and growth (Nickla et al., 1999; Wiechmann et al., 2004).

Xenopus leavis is a frog whose eye exerts a pineal-like function as it produces the melatonin that is released into the blood. The $\mathrm{MT}_{1}$ receptor is present in the outer and inner fibrous layer of the sclera of Xenopus laevis, and to a lesser extent in the cartilaginous layer (Wiechmann and Rada, 2003). In this frog, $\mathrm{MT}_{2}$ receptor is present in the distal portion of the outer fibrous layer, but not in the inner fibrous layer. Existing data suggest that the $\mathrm{MT}_{2}$ receptor is the main melatonin receptor in the lens fiber cells of Xenopus laevis (Wiechmann et al., 2004). It is suggested that $\mathrm{MT}_{2}$ receptors are the target of melatonin synthesized by the human lens in which AANAT activity is modulated by light/dark cycles. Indeed the expression of the enzyme is markedly enhanced at night (Fig. 3) (Abe et al., 1999; Alkozi et al., 2017d). It should be noted that melatonin protects against cataracts produced by ultraviolet light or by oxidative stressors such as buthionine sulfoximine (Abe et al., 1994; Bardak, 2000).

The iris regulates the amount of light entering the eye, while the ciliary body is mainly responsible for aqueous humor production. Melatonin receptors are expressed in these structures (Osborne and Chidlow, 1994) (Dortch-Carnes and Tosini, 2013) and in the cornea, the most superficial structure of the eye facing all of the stress coming from the environment (DelMonte and Kim, 2011). In mammals, melatonin receptor $\mathrm{MT}_{2}$ was detected in corneal epithelium and endothelium and its activation affects circadian rhythm entrainment (Baba et al., 2015). Additionally, $\mathrm{MT}_{2}$ receptors play a role in corneal wound healing (Crooke et al., 2015).

The wide distribution of melatonin receptors in the eye and the differential expression of $\mathrm{MT}_{1}$ and $\mathrm{MT}_{2}$ receptors in the ocular structures suggest multiple functions that will require more experimental effort for complete elucidation (Wiechmann et al., 2004).

\section{Aqueous humor and intraocular pressure}

Early results from measuring IOP in a large healthy population (10,000 individuals) showed a Gaussian distribution with a mean of 15-16 \pm 2 mmHg (Leydhecker et al., 1958). Ulterior studies confirmed those values and the reference values were established in the 9-21 mmHg range (Colton and Ederer, 1980). Abnormal values are those found in 97.5 percentile and, in practice, eye hypertension is considered when IOP $>21 \mathrm{~mm} \mathrm{Hg}$. Elevated eye tension is not considered a pathological process per se, although it constitutes a risk factor for certain ocular pathologies such as glaucoma (Casson et al., 2012a).

IOP constitutes the physical substrate needed to keep intraocular structures in place. In fact, the intraocular pressure is a result of a hydrostatic balance in which the aqueous humor, the lens, the vitreous, the uvea and the corneoscleral wall (the container) participate (Aptel et al., 2016). Its value is kept within a narrow range thanks to a dynamic equilibrium between the production and drainage of the aqueous humor. Although episcleral vein pressure and circadian rhythms also contribute to IOP, the main issue in ocular hypertension is the
A
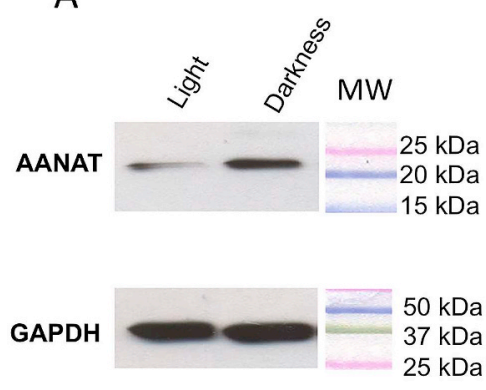

B

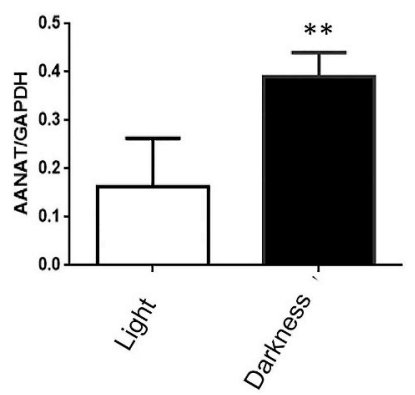

C
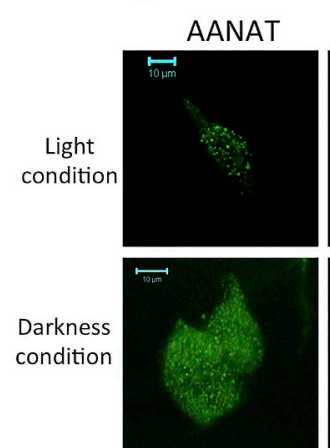
Nucleus
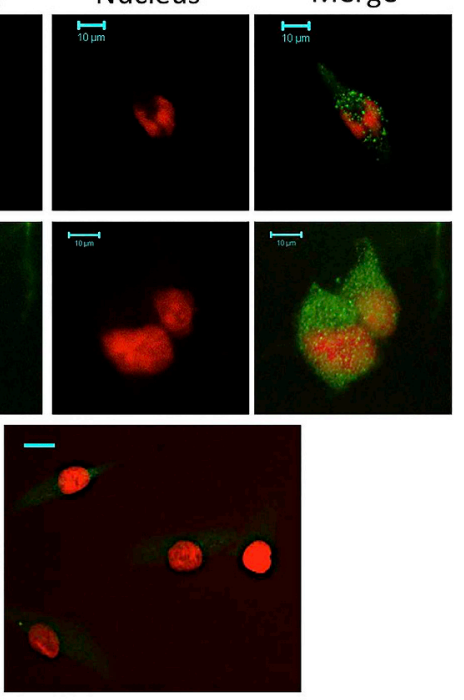

Fig. 3. Light-induced effect on AANAT expression in human lens epithelial cells. Panels A-B: Analysis by Western-blot of AANAT expression after $8 \mathrm{~h}$ of light or darkness. Values in B are the mean \pm SD $\left(\mathrm{n}=6 ;{ }^{* * \mathrm{p}}<0.01\right)$. Panel C: Immunohistochemical study performed in human lens epithelial cells showing the changes in AANAT expression (nuclei appear in red). A negative control was performed using human chondrocytes. Taken from (Alkozi et al., 2017d) with permission (Elsevier). 
alteration in the balance between production and drainage of the aqueous humor (Brubaker, 1991).

The aqueous humor is a transparent fluid, somewhat similar to blood plasma, that bathes the anterior and the posterior ocular chambers (Adler, 1933; Civan and Macknight, 2004; Davson et al., 1936). It is secreted into the posterior chamber by cells in the ciliary processes, it circulates through the pupil and passes into the anterior chamber from where it is drained by two main routes, the conventional pathway (trabecular meshwork-Schlemm's canal-aqueous veins), and the nonconventional uveoscleral drainage pathway (Bill, 1966). The circulation of the aqueous humor serves to a myriad of functions such as providing oxygen and nutrients to the cornea, lens, and trabecular meshwork, but also to the pressure needed for avoiding eye collapse (Krupin et al., 1986).

The aqueous humor dynamics changes according to circadian rhythms. For instance, the rate of aqueous humor formation in humans drops from $2.6 \mu \mathrm{l} / \mathrm{min}$ during daytime to $1.1 \mu \mathrm{l} / \mathrm{min}$ at night (McCannel et al., 1992); therefore IOP is lower at night. These circadian changes in IOP values are due to the communication between the ciliary body and the suprachiasmatic nucleus and to several regulatory signals, for instance those exerted by norepinephrine, cAMP, adenosine, dopamine, and melatonin. However, circadian fluctuations in a healthy eye are very limited, i.e. they lie within a $3-5 \mathrm{mmHg}$ range (Coca-Prados and Escribano, 2007; Osborne and Chidlow, 1994).

The nervous control of IOP is exerted by both sympathetic (adrenergic) and parasympathetic (cholinergic) systems (Bergmanson, 1982). The origin of adrenergic nerves lies in the fibers coming from the ipsilateral superior cervical ganglion. Each ciliary process contains adrenergic nerves, although the density of such innervation varies across species (Ehinger, 1966; Ehinger et al., 1969). The parasympathetic cholinergic nerves originate in post-ganglionic fibers of the pterygopalatine ganglia, which originate from preganglionic neurons in the superior salivary nucleus located in the dorsal pons (pontine tegmentum) in the brainstem. These post-ganglionic fibers innervate the structures involved in intraocular pressure regulation, e.g. the ciliary epithelium and trabecular meshwork (Ten Tusscher et al., 1990).

IOP is not only controlled by aqueous production routes but by receptors present in aqueous humor outflow drainage pathways (Nomura and Smelser, 1974; Selbach et al., 2000). The link between IOP and both adrenergic and cholinergic receptors was established by the use of pharmacological tools; in this sense, phenylephrine, the endogenous adrenoceptor agonist reduces the junctions between pigmented and non-pigmented ciliary processes in cows and rabbits. Similar results were observed using carbachol, a cholinergic receptor agonist. A reduction in the interfaces between both pigmented and non-pigmented epithelium layers, together with inhibition of adenylyl cyclase, are responsible of reducing aqueous humor production (Shi et al., 1996). Cholinergic agonists such as pilocarpine are used to reduce resistance of aqueous outflow through the trabecular meshwork (Diestelhorst et al., 2002). It was reported that agonists of $\alpha_{1}$-receptors increase IOP, whereas agonists and antagonists of $\alpha_{2}$-receptors inhibited aqueous humor outflow less than production, thus leading to IOP decreases; authors concluded that "The conventional theory of receptor antagonism does not seem to function at $\alpha_{2}$-receptor sites" (Chiou, 1983). Probably the results of $\alpha_{2}$-adrenoreceptor agonists are dual as they also affect trabecular meshwork resistance (Hodapp et al., 1981). Activation of $\beta$ adrenoceptors in the healthy human eye, for instance using salbutamol, consistently leads to increase of uveoscleral outflow and decrease in IOP (Coakes and Siah, 1984). These findings have been instrumental for the design of medications prescribed today to reduce IOP.

\subsection{Glaucoma: from pathology to therapy}

According to the US National Eye Institute (NIH-NEI), glaucoma is "a group of diseases that damage the eye's optic nerve and can result in vision loss and blindness". Often, glaucoma is a disease resulting from increased scleral rigidity occurring upon aging. Neurodegeneration affects retinal ganglion cell death and courses with reduction of axons in the optic nerve. Aging is a risk but, interestingly, NIH-NEI indicates that the risk is higher in "African Americans over age 40 and everyone over age 60, especially Mexican Americans" (Facts About Glaucoma, 2015) (https:// nei.nih.gov/health/glaucoma/glaucoma_facts). Genetic factors also contribute and the risk increases if progenitors or grandparents have suffered from glaucoma (Casson et al., 2012b; Quigley, 2011). Glaucoma is considered the second leading cause of blindness and the first if only irreversible blindness is considered. A study done in 2006 has estimated about 61 million individuals suffering from glaucoma. It is estimated that, by 2020, glaucoma will affect 80 million persons (Quigley and Broman, 2006).

Two different glaucoma types must be highlighted: the angle-closure disease is due to a mechanical narrowing in the irido-corneal outflow structures, whereas the open-angle glaucoma occurs without marked changes in the shape of these structures (Casson et al., 2012b; Foster et al., 2002). Nearly three quarters of all glaucoma cases occurs in individuals with open irido-corneal angle, i.e. open-angle glaucoma is the most common form of the disease in virtually all countries. The vast majority is idiopathic and, therefore, is referred to as primary open-angle glaucoma (POAG) (Quigley and Broman, 2006). Up to $40 \%$ disappearance of nerve fibers of the retina can happen without any gross manifestation of functional loss in open-angle glaucoma (Foster and Johnson, 2001); see (Pan and Varma, 2011) for review and historical perspective. The disease may affect one or both eyes and the first clinical symptom consists of loss of peripheral vision. Open angle glaucoma may occur without increase in IOP and, conversely, not all individuals with eye hypertension develop glaucoma. When open-angle glaucoma correlates with increased IOP, the measurement of this parameter is instrumental to control for the efficacy of pharmacological treatments (Liu et al., 2018).

Numerous factors impact on the initiation of neurodegeneration: among other, ageing, intraocular pressure, and marked myopia (Quigley, 2011). This condition is named the silent thief of sight since it is asymptomatic and, if untreated, leads to vision loss. Glaucoma does not necessarily mean that IOP is above reference values. Actually, openangle glaucoma defining criteria do not include elevated IOP. However, prevention measures include IOP measurement as it is easy to measure and it is indeed an associated risk factor (Leske, 2007; Quigley, 2011). Furthermore, lowering IOP is considered the first therapeutic approach, even in patients presenting IOP readings within reference values (Danias and Podos, 1999; Leske et al., 1999).

It is proven that IOP lowering prevents progression of the disease, i.e. retards visual field loss and protects optic nerve (Boland et al., 2013). Pharmacological lowering of IOP using eye drops, or laser intervention in the trabecular meshwork, are preferred than the more aggressive surgical procedures (Ederer et al., 2004). A common and effective surgical approach is trabeculectomy surgery, which consists of making a small incision in the sclera to introduce a bleb allowing control on aqueous humor drainage (Quigley, 2011). To reduce the ocular hypertension with eye drop galenic formulations, parasympathomimetic drugs, adrenergic receptor antagonists, carbonic anhydrase inhibitors or prostaglandins have been approved for human therapy (Hommer, 2010; Lee, 2005). The range of IOP decrease is $20-40 \%$, which is usually efficacious in preventing vision loss with the exception of patients presenting fast progression (Quigley, 2011).

Despite the numerous pharmacological options to lower IOP, they are not absent of undesirable adverse reactions. $\beta$ blockers may worsen dry eye symptoms and conjunctival hyperemia but, more importantly they may provoke bradycardia, arrhythmia and bronchospasms (Hoyng and van Beek, 2000). Prostaglandins use may end up in headache, upper respiratory tract alterations, iris pigmentation, uveitis and/or reactivation of herpetic keratitis (Marquis and Whitson, 2005). Carbonic anhydrase inhibitors could produce ocular stinging, burning, itching and, in some cases, they may alter the corneal endothelium in 
an irreversible fashion (Konowal et al., 1999). There is still a demand for new tools to combat glaucoma with less side effects (Pintor et al., 2003). In the meantime adverse events are managed by combining different drugs and/or combining periods of treatment with one drug with periods of treatment with a drug of another class (Polo et al., 2001; Sakai et al., 2005).

\subsection{Mechanisms to reduce IOP}

IOP decrease may be achieved by either regulating the aqueous humor formation or by facilitating the flow through the trabecular meshwork. Agents used to reduce aqueous inflow are $\beta$-adrenergic antagonists, carbonic anhydrase inhibitors, and $\alpha_{2}$-adrenergic agonists. As for $\beta$-adrenergic antagonists, a topical instillation of this agent leads to decreases in cAMP in ciliary epithelial cells and, accordingly, reduction in the aqueous humor production (Coakes and Brubaker, 1978). Inhibitors of isozymes of carbonic expressed in ciliary processes increase bicarbonate ion and result in decreased aqueous humor secretion (Mincione et al., 2007). The mechanism proposed for $\alpha_{2}$-adrenergic agonists involves a Gi-mediated vascular constriction; a reduction in cAMP would reduce phosphorylation of myosin light chain kinase by PKA. Prevention of vascular relaxation would decrease blood flow and aqueous humor formation (Reitsamer et al., 2006; Remaury et al., 1993). Mechanisms underlying the efficacy of prostaglandin analogues and prostamides are not known although these molecules act on the trabecular meshwork where they alter permeability and allow uveoscleral outflow to consequently decrease IOP (Crichton et al., 2013; Gaton et al., 2001).

\subsection{Melatonin: a relevant player in IOP regulation}

In several species including humans, the IOP follows a circadian rhythm just inversely as that of melatonin. IOP is higher during the day, when [melatonin] (in the CNS, the blood and the eye) displays lower values. This relationship occurring in daytime also applies at night time (Wurtman et al., 1963). Therefore, it was temping to speculate that melatonin could be behind changes in IOP; this hypothesis was correct as demonstrated in different laboratories (al-Qassab et al., 1988; Belforte et al., 2010; Chiou and McLaughlin, 1984; Pintor et al., 2001). Remarkably, melatonin levels may be significantly altered in eye pathologies, for instance, in glaucoma (Ma et al., 2018). In this sense, studies analyzing melatonin levels in the aqueous humor of patients having cataract surgery showed that normotensive cases (IOP < $21 \mathrm{mmHg}$ ) had lower melatonin levels than individuals having elevated IOP (IOP > $21 \mathrm{mmHg}$ ) (Fig. 4) (Alkozi et al., 2017a). This finding

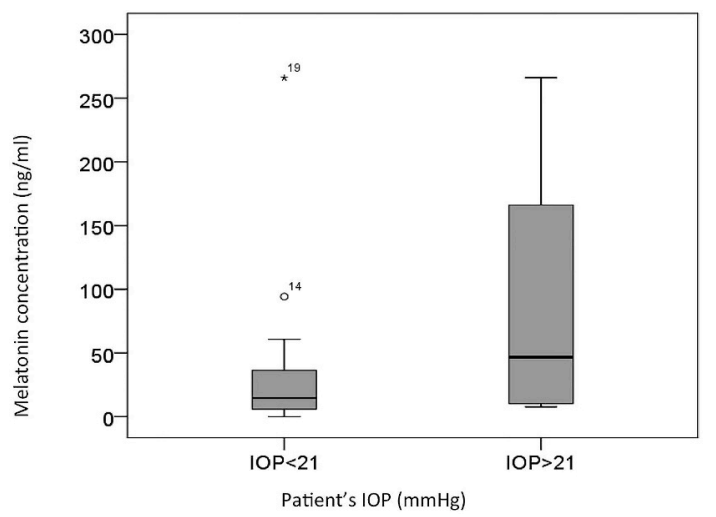

Fig. 4. Panel A: HPLC was used to isolate and quantify melatonin from human aqueous humor samples of patients with IOP above $21 \mathrm{mmHg}$ and below $21 \mathrm{mmHg}$. The bar plot shows the concentration of melatonin in the two populations of patients (*p $<$ 0.039). Taken from (Alkozi et al., 2017a) with permission (Wiley). correlates with another in which [melatonin], measured in blood, was higher in patients with glaucoma (Ma et al., 2018). Furthermore, when aqueous humor of a glaucomatous model (DBA/2J) is compared with that of control mice (C57BL/6J), it is shown that melatonin levels are similar in control and DBA/2J before the establishment of pathology. However, aged DBA/2J mice, which overtly present eye hypertension, display increased levels of the indoleamine. The model also shows a linear correlation between IOP and the melatonin concentration (Fig. 5) (Alkozi et al., 2017a). Increase in concentration is also evident in the aqueous humor of patients suffering from proliferative diabetic retinopathy, albeit in this case the levels in blood are not altered. Taken together, the results indicate that the increase of melatonin in the eye of glaucoma patients is mainly produced by ocular structures and it is not due to melatonin coming from the pineal gland (Aydin and Sahin, 2016).

The reported results cannot explain why melatonin is increased in glaucoma coursing with eye hypertension when the compound itself is able to lower IOP (Ismail and Mowafi, 2009). Interestingly, melatonin and its analogues such as agomelatine or methoxycarbonylamino-Nacetyltryptamine (5-MCA-NAT), when topically applied to normotensive eyes of control animals or to hypertensive eyes of aged DBA/2J mice, are able to afford a significant decrease in IOP (Crooke et al., 2013; Martinez-Aguila et al., 2013, 2016).

Non-pigmented ciliary body epithelial cells are likely responsible for the changes of melatonin levels due to increased IOP. Activation in these cells of a channel sensitive to mechanical pressure, the vanilloid transient receptor potential channel 4, TRPV4, results in increased melatonin production (Alkozi and Pintor, 2015). TRPV4 was first identified as an osmosensor, i.e. a stretch-gated channel. At present, it is acknowledged that it is not a classical osmosensor but a regulator of numerous events in both physiological and pathological conditions (Liedtke, 2007). The polyvalent mode of action of TRPV4 is essential for osmoregulation and $\mathrm{Ca}^{2+}$ homeostasis in the mammalian ciliary body (Jo et al., 2016). The TRPV4 is expressed in secretory and absorptive epithelia, regulating $\mathrm{Ca}^{2+}$ signalling and cytoskeletal remodeling, and responding to volume changes, shear flow and mechanical stress (Harteneck and Reiter, 2007; Krizaj et al., 2014; Mamenko et al., 2015; Sokabe et al., 2010).

GSK1016790A, a selective TRPV4 channel agonist, leads to a dosedependent increase in melatonin levels, that is abolished by selective TRPV4 antagonists (Alkozi and Pintor, 2015). Due to the correlation between melatonin levels and IOP in glaucoma patients, it is suggested that the channel acts in the ciliary body as a pressure sensor. The mechanism of melatonin synthesis induction following TRPV4 activation consists of an increase in AANAT activity. Upon TRPV4 activation, AANAT expression is enhanced and the levels of both melatonin and NAS in the extracellular medium of human ciliary body cells raise, i.e. these cells are able to produce the indolamine (Fig. 6) (Alkozi et al., 2017c). A small interference siRNA approach confirmed that all those effects are mediated by TRPV4 (Alkozi et al., 2017b). In summary, the activation of the channel results in a significant increase in the activity of the melatonin-synthesizing enzyme (AANAT).

One relevant aspect of AANAT concerns its degradation, which is regulated by phosphorylation/dephosphorylation. The human AANAT amino acid sequence contains a conserved casein kinase and a putative protein kinase C phosphorylation sites (Coon et al., 1996). Second messengers and signal transduction events affect the degree of enzyme phosphorylation and it is thought that decreases in [cAMP] leads to a decrease in AANAT activity (Klein, 1978; Klein et al., 1992). It seems, however, that cAMP may also regulate proteasome action on AANAT (Gastel et al., 1998). AANAT may bind to regulatory 14-3-3 proteins that are expressed as dimers. Complex rearrangements occur at night by cAMP-dependent phosphorylation of the enzyme resulting in activation and protection against proteolysis (Muslin et al., 1996). In the human pineal gland, AANAT bind and stabilize 14-3-3 proteins. More precisely, two pAANAT molecules form a moderately stable complex with two 14- 
A

B

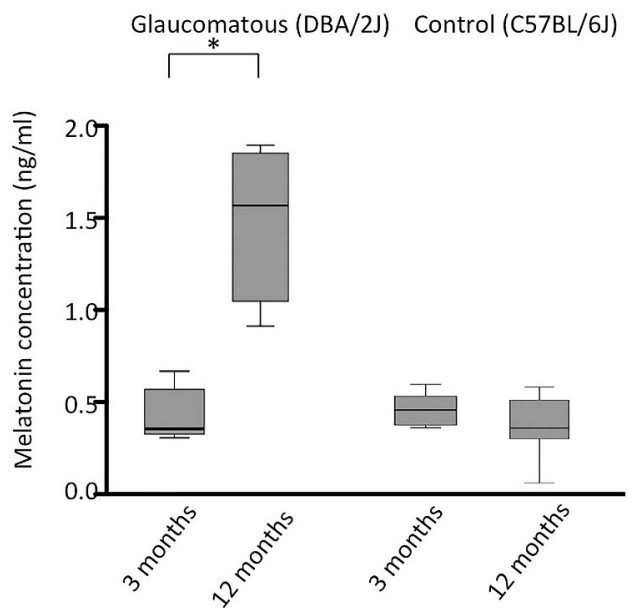

Fig. 5. Correlation between melatonin concentration and IOP. Melatonin concentration in the aqueous humor of control (normotensive) and glaucomatous DBA mice. Melatonin was isolated by HPLC and levels were compared in animals (C57 and DBA) at 3 an 12 months of age (*p $<0.001$; Wilcoxon for paired samples). Panel B: Relationship between melatonin concentration $(\mathrm{ng} / \mathrm{ml})$ in aqueous humor of glaucomatous (DBA2/J) and nonglaucomatous (C57) mice strains and the IOP was statistically significant (Pearson correlation analysis: $\mathrm{p}<0.001 ; \mathrm{r}=0.851$ ). Modified from (Alkozi et al., 2017a) with permission (Wiley).
3-3 proteins, which undergo dissociation/re-association cycles. When dissociated pAANAT is dephosphorylated, it does not re-associate while it is degraded. This mechanism plays an important role in regulating melatonin diurnal synthesis. Indeed, it has been demonstrated that in darkness, when the complex is formed, the amount of melatonin produced in the pineal gland can increase by 10 fold (Jones et al., 1995; Klein et al., 2002).

Interestingly, the degree of AANAT phosphorylation correlates with TRPV4 functionality. Application of a selective agonist of TRPV4 expressed in non-pigmented ciliary body epithelial cells results in a robust increment of AANAT phosphorylation (Alkozi et al., 2017b). As a consequence, phosphorylated AANAT is more active and more melatonin is produced and released to the extracellular medium. The intracellular chain of events in these cells involve the calmodulin-dependent protein kinase II (CAMPKII) (Alkozi et al., 2017b). In fact, the sequence of human AANAT (GenBank: AAH92430.1) includes consensus site for CAMPKII action (Pearson and Kemp, 1991; Songyang et al., 1996). This pathway in eye-derived cells is different from the "canonical" pathway in the pineal gland that is dependent on elevation of cAMP levels and PKA-dependent AANAT phosphorylation (Fig. 7) (Schomerus and Korf, 2005).

On the one hand, the participation of the TRPV4 channel in regulating AANAT activity and melatonin production in ciliary processes could explain the increase in melatonin levels found in the aqueous humor of patients with elevated IOP. On the other hand, it is suspected that other factors impact on this issue, namely melatonin found in the aqueous humor can come from other ocular cells.

A novel discovery in the epithelial cells of crystalline lens, another structure where melatonin is synthesized (Abe et al., 1999), is the presence of functional melanopsin (Alkozi et al., 2017d). One of the functions of this light-responding receptor is the control of melatonin synthesis; its activation by the short wavelength component of the light leads to melatonin suppression (Quera Salva et al., 2017). Melanopsin is a photosensitive protein, that mechanistically sustains the discovery (in the 1920s) of Clyde Keeler, who noticed that rodless and coneless mice could still respond to light stimulus by pupil constriction (Keeler,

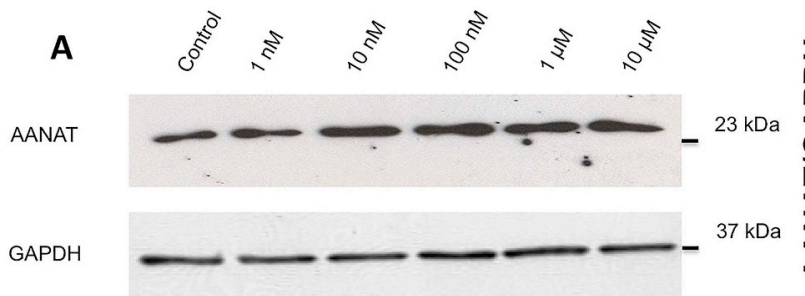

B
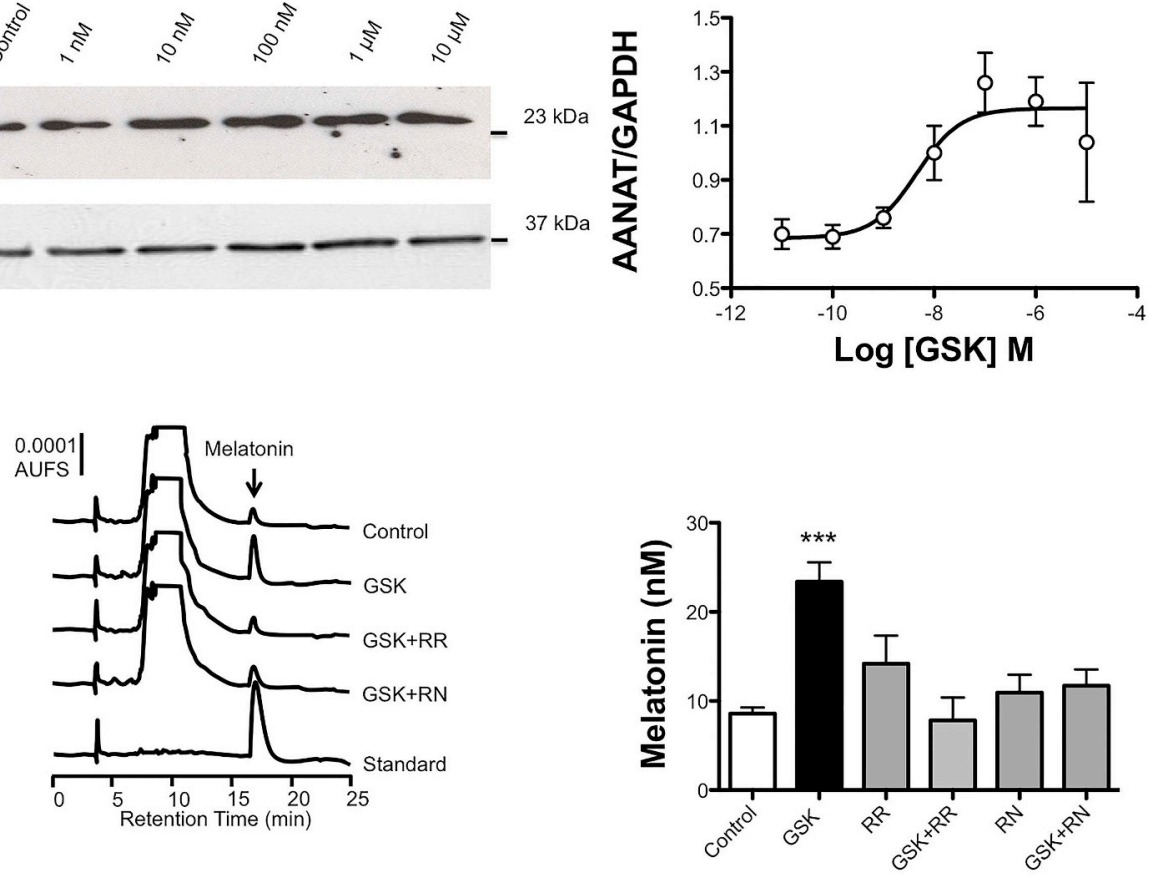

Fig. 6. Activation of TRPV4 expressed in human ciliary body epithelial cells induces the expression of AANAT and melatonin synthesis. Panel A: Dose-response data using different concentrations of the TRPV4 agonist. Data are the mean \pm SEM $(n=5)$. Panel B: Time-course of the effect of GSK1016790A on melatonin synthesis. Values represent the mean \pm SEM (n $=6 ; * \mathrm{p}<0.05, * * \mathrm{p}<0.01$, $* * * \mathrm{p}<0.001$ versus time 0 ). Taken from (Alkozi et al., 2017c: open access). 


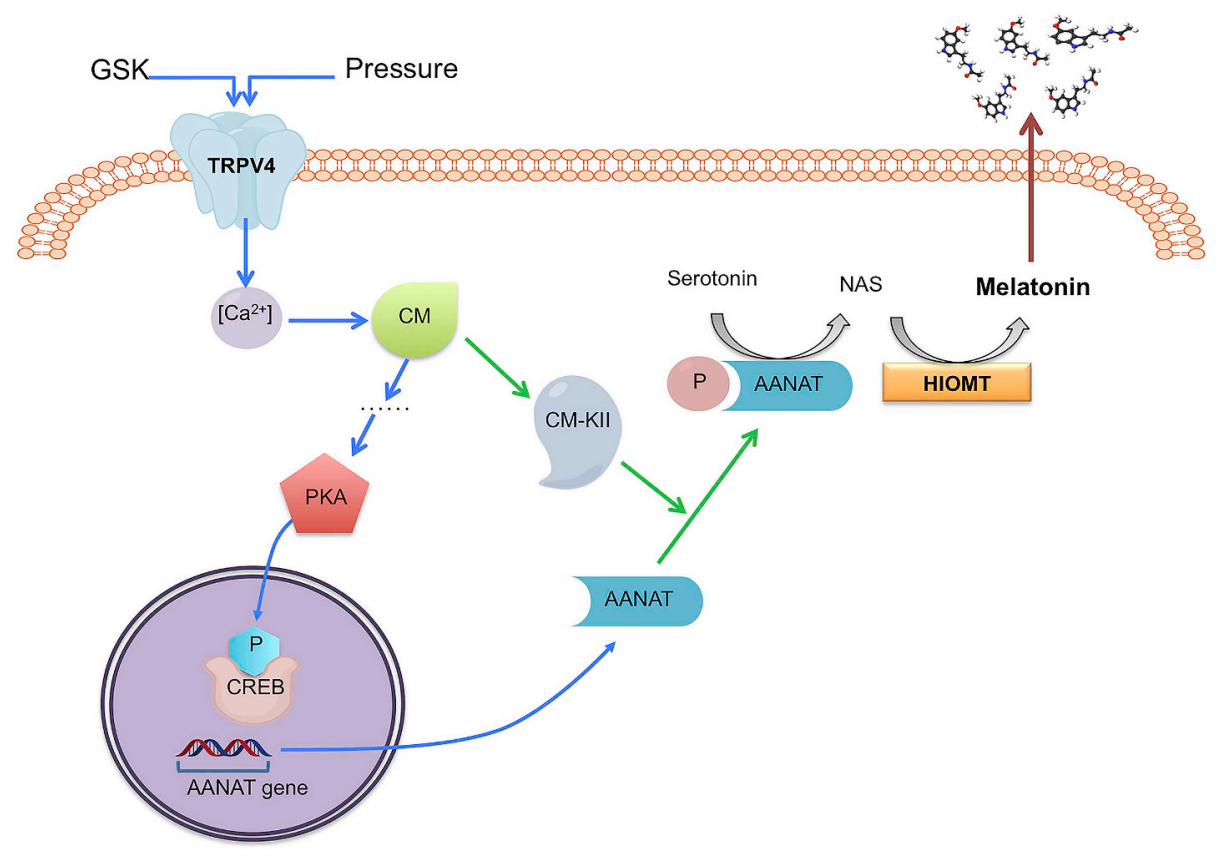

Fig. 7. Scheme of events in the ciliary body triggered upon TRPV4 channel activation. Upon agonist activation of TRPV4 using GSK1016790A, a $\mathrm{Ca}^{2+}$ influx occurs and the ion binds to calmodulin (CM) to indirectly activate adenylyl cyclase and protein kinase A (PKA). This kinase will finally produce the phosphorylation of cAMP response-element-binding (pCREB) thus promoting the synthesis of the enzyme AANAT. On the other hand, CM binds to calcium-CM dependent kinase II to phosphorylate AANAT. This protein together with HIOMT will finally augment the production of melatonin in ciliary body epithelial cells. It should be noted that TRPV4 channel can be stimulated by the abnormal elevation in the IOP often occurring in glaucoma.

1928). This was the first evidence of a photoreceptor in the eye; several years later Provencio and colleagues identified a small sub-class of retinal ganglion cells expressing a photosensitive "receptor", melanopsin (Provencio et al., 2000). Light activation of this receptor leads to cell depolarization whereas light leads to hyperpolarization in rods and cones (Qiu et al., 2005). After light stimulation, melanopsin in retinal ganglion cells triggers signalling via $\mathrm{Gq} / 11$, thus leading to the activation of phospholipase C (PLC), hydrolysis of phosphatidylinositol 4,5bisphosphate $\left(\mathrm{PI}(4,5) \mathrm{P}_{2}\right)$ and subsequent increase in cytosolic $\mathrm{Ca}^{2+}$; overall, light leads to depolarization of the plasma membrane of retinal cells containing the receptor (Koyanagi and Terakita, 2008; Valdez et al., 2009). When light activates melanopsin, signals are transmitted from the retina through the retinohypothalamic tract to the suprachiasmatic nucleus (SCN) and to the cervical superior ganglion and the pineal gland where melatonin synthesis is suppressed (Quera Salva et al., 2017).

Recently, melanopsin presence in the cornea and the crystalline lens was identified (Alkozi et al., 2017d; Delwig et al., 2018). Studies using human crystalline epithelial cells showed that different light conditions were able to produce changes in melatonin levels in the extracellular medium, in fact, blue light activated melanopsin protein leading to melatonin reduction in comparison to cells incubated under constant darkness or red light. This action was mediated by phospholipase C (PLC) as in the case of melanopsin activation in retinal ganglion cells. These changes in melatonin levels also correlated with the activity of AANAT (Alkozi et al., 2017d). Light ability to regulate in the lens both melatonin levels and the activity of synthesizing enzymes is a relevant factor to consider. Further studies are needed to relate these findings with melatonin concentration in eye hypertension. Work using New Zealand white rabbits revealed circumstantial evidence for such link. Animals under 12/12 light/darkness cycles but only exposed to yellow light had a decrease in IOP in comparison to control animals living under dark/white light standard cycles. The results were concomitant with an elevation of melatonin levels in the aqueous humor; moreover, ocular hypotensive effect was blocked by the instillation of melatonin receptor antagonists. Blockade by luzindole, a non-selective melatonin receptor antagonist and by 4-P-PDOT, a $\mathrm{MT}_{2}$ selective antagonist, confirmed that the effect was mediated by melatonin receptors (Lledo et al., 2019). These findings are of significant relevance since an environmental factor, light, regulates melatonin content by directly acting on the eye and, furthermore, on doing so it also regulates IOP (Pintor,
2018).

\subsubsection{Melatonin and its analogues are efficacious ocular hypotensives}

Is melatonin efficacious to reduce IOP in patients with glaucoma that already have elevated levels of the indoleamine? (Martinez-Aguila et al., 2016). As earlier mentioned, melatonin is an efficacious hypotensive agent when applied to normotensive eyes. Patients undertaking cataract surgery are given oral tablets of melatonin $(10 \mathrm{mg}$; before the surgery). In these patients with normotensive eyes (IOP: $17.9 \mathrm{mmHg}$ ) melatonin significantly reduces IOP to $13.8 \mathrm{mmHg}$ during cataract surgery. This intervention is known to result in better surgical conditions and outcomes (Ismail and Mowafi, 2009). On the other hand, reduction in IOP may be achieved in glaucoma patients using agomelatine, a melatonin analogue used as anti-depressant (Pescosolido et al., 2015). Moreover, topical instillation of agomelatine in New Zealand white rabbits resulted in a similar IOP reducing effect in both normotensive and hypertensive conditions (Martinez-Aguila et al., 2013).

A significant number of melatonin analogues have shown hypotensive efficacy: melatonin itself, N-acetyltryptamine, 6-chloromelatonin, 2-iodomelatonin, 2-phenylmelatonin and 5-MCA-NAT. While all were efficacious in New Zealand white rabbits, 5-MCA-NAT was the most efficacious (42.5\% IOP reduction). More interestingly, 5MCA-NAT displayed a sustained effect which lasted for more than $8 \mathrm{~h},>3 \mathrm{~h}$ more than that of other tested compounds (Pintor et al., 2003). This effect of 5-MCA-NAT was thought to be mediated by the putative $\mathrm{MT}_{3}$ melatonin receptor (Pintor et al., 2001). The promising potential of 5-MCA-NAT in reducing IOP, was confirmed in a timecourse study that revealed that a single dose of the compound may lower IOP for up to $96 \mathrm{~h}$ (Crooke et al., 2012). Carbonic anhydrases affect aqueous humor secretion (Brechue and Maren, 1993), in fact, their inhibitors are used to reduce IOP, either alone or in combination with timolol, a $\beta$-blocker (Turk et al., 2015). Studies conducted to understand the mechanisms underlying the hypotensive effect of 5-MCANAT and to check if the compound regulated the transcription of carbonic anhydrase genes did not serve to identify the molecular mode of action. On the one hand, the combination of 5-MCA-NAT and a carbonic anhydrase inhibitor approved for therapy, dorzolamide, had stronger hypotensive capacity, something that does not fit with a carbonic-anhydrase-mediated action. On the other hand, using the New Zealand white rabbit as a model, 5-MCA-NAT significantly decreased the expression of carbonic anhydrase 2 (CAII) and 12 (CAXII) in in vivo 
and in vitro assays (Crooke et al., 2012). Accordingly, 5-MCA-NAT likely reduces IOP by a carbonic anhydrase-independent mechanism.

Interestingly, in vitro studies in non-pigmented ciliary body epithelial cells revealed that melatonin and 5-MCA-NAT were able to significantly down regulate the expression of the $\beta_{2}$-adrenergic receptor while causing $\alpha_{2 \mathrm{~A}}$ receptor up-regulation. These results are relevant since adrenergic receptors are important players in regulating the aqueous humor production in the ciliary processes (Greenfield et al., 1997). Accordingly, when New Zealand white rabbits were primed with melatonin or 5-MCA-NAT, and then daily treated with either timolol (non-selective $\beta$-adrenergic receptor antagonist) or brimonidine (selective $\alpha_{2 \mathrm{~A}}$-adrenergic agonist), melatonin and 5-MCA-NAT potentiated the hypotensive effect of the adrenoceptor-acting drugs (Crooke et al., 2013). It is noteworthy to comment that combined therapy for the control of glaucoma is a common method when monotherapy is no longer effective (Sakanaka et al., 2008), therefore, melatonin used either in combination with other agents or only as pre-treatment could be effective to achieve stronger and long lasting hypotensive effect. Moreover, the application of IIK7, a selective $\mathrm{MT}_{2}$ receptor agonist and melatonin analogue, afforded a $38.5 \%$ IOP reduction. The effect was severely diminished after chemical sympathectomy using reserpine or 6-hydroxydopamine (Alarma-Estrany et al., 2007). Taken together these results suggest that IOP reduction by IIK7 or melatonin is mediated mainly by $\mathrm{MT}_{2}$ receptors and that targeting the $\beta$-adrenoceptor maximizes the effect.

Eye retinal pigment functionality in vertebrates is key to preserve a correct activity of retinal neurons. Disfunction of epithelial ion transport mechanisms can electroretinogram, which measures electrical activity (Gallemore et al., 1997). The DBA/2J mice, which develops glaucoma at 9 months of age, as shown by high IOP values and marked alteration in the electroretinogram (Fig. 8), is instrumental as it is considered a model of glaucoma that, furthermore, presents markedly high IOP values at the onset of hypertension (Perez de Lara et al., 2014). Experiments using this model proved that melatonin was able to normalize IOP; melatonin had a hypotensive effect of $19.4 \%$ in control mice, and $32.6 \%$ when applied to the eye of the glaucoma DBA/2J mice model (Martinez-Aguila et al., 2016). Melatonin has been also tested in the model of elevated intraocular pressure induced by the Trendelenburg position (Mizumoto et al., 2017), which consists of placing the animal at $80^{\circ}$ with the head in a lower position with respect to the rest of the body. The position is maintained for $20 \mathrm{~min}$ and the pharmacological treatment is made $2 \mathrm{~h}$ after animal resting. This methodology assayed using New Zealand rabbits proved that melatonin and agomelatine were effective. Agomelatine applied to normotensive animals reduced IOP by $21 \%$, while in the hypertensive condition, the effect of the compound was huge (69\%) (Martinez-Aguila et al., 2013). In summary, melatonin and analogues are even more effective hypotensives when hypertensive glaucoma is established.

In view of the remarkable effect that 5-MCA-NAT was producing over IOP, and to confirm the long lasting effect and safety of this melatonin's analogue, glaucoma was induced in another animal model; the non-human primate Macaca fascicularis in which trabecular meshwork is photocoagulated. 5-MCA-NAT application in this model

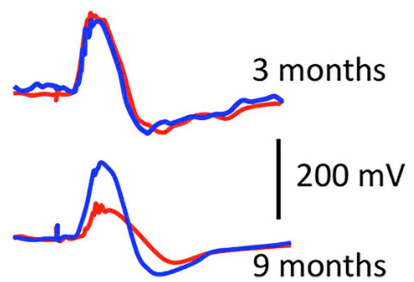

Fig. 8. Electroretinogram in control C57BL/6J (blue) and DBA/2J (red) mice. Positive scotopic threshold response (pSTR) amplitude was significantly reduced in the DBA/2J glaucomatous at 9 months of age ( $\mathrm{p}<0.00001)$. Taken from (Alkozi et al., 2019). confirmed that the compound is capable of afford both significant and long lasting IOP reduction. More importantly, the treatment was safe with no signs of ocular side effects or systemic adverse reactions (Serle et al., 2004).

\subsubsection{Recent advances in melatonin-receptor-mediated mechanism leading to IOP decrease}

In vivo studies showed that melatonin receptor activation is the main cause of IOP reduction (Pintor et al., 2003). $\mathrm{MT}_{1}$ and $\mathrm{MT}_{2}$ receptors belong to the superfamily of G-protein-coupled receptors (GPCRs) that is the largest class of cell surface receptors within the mammalian proteome. Interestingly, about a $40 \%$ of all current prescription drugs target GPCRs (Drews, 1996; Prinster et al., 2005). The current pharmacology of melatonin receptors suggests that targeting the receptors in individual fashion cannot explain why its activation leads to IOP reduction, especially when there is both hypertension and increased melatonin levels. Among the various alternative mechanisms, functional units constituted by melatonin receptors in complex with other proteins must be considered.

Usually described as receptors acting individually, more than 600 entities have been described that are constituted by (at least) two GPCRs (Borroto-Escuela et al., 2014). Indirect evidence suggesting a direct interaction between GPCR receptors (Krawietz et al., 1979; Limbird et al., 1975) was followed by observations (in the early 80s), showing that substance $\mathrm{P}$ could modulate the high-affinity serotonin binding sites in spinal cord membrane preparations using biochemical binding techniques (Agnati et al., 1980). Fuxe, Agnati and colleagues emitted then the hypothesis of direct receptor-receptors interactions that, around 20 years later, was proved. Identification of a heteromer constituted by two receptors for the same endogenous opioid peptides (Gomes et al., 2000) was followed by identification of the first heteromer constituted by GPCRs for two different neurotransmitter/neuromodulators (Gines et al., 2000). Ulterior development of ad hoc techniques, for instance Bioluminescence Energy Resonance Transfer (BRET) (Angers et al., 2000), has allowed advances in the discovery of several GPCRs heterodimers, even heteromultimers, getting insight into their physiological role. Occurrence of GPCR heteromers and differential expression in diseases (Bonaventura et al., 2014; Pinna et al., 2014) has paved the way of a new area of research that opens a myriad possibilities from both physiological and pharmacological points of view. First of all, it should be highlighted that GPCR heteromers, by definition, display properties that are new, i.e. not displayed by receptors when individually expressed (Ferre et al., 2009). In addition to fundamentally changing our views on the quaternary structure and activation mechanism, the concept of homo- and hetero-dimerization may have a dramatic impact on drug development and screening (Prinster et al., 2005). GPCR heteromerization appears as a good substrate to explain previously unexpected pharmacological profiles and signalling patterns. The challenge of translating findings in heterologous systems to physiological environments has been solved by means of two complementary approaches, namely by detection of the so-called heteromer fingerprint (Franco et al., 2016) and by imaging receptor clusters using the in situ proximity ligations assay (Agnati et al., 2003; Borroto-Escuela et al., 2014; Soderberg et al., 2006).

There is now cumulative evidence showing that melatonin receptor as other GPCR do form heteromers that are functionally relevant (Prinster et al., 2005). It has been reported that $\mathrm{MT}_{1}$ and $\mathrm{MT}_{2}$ receptors may form heteromers in a heterologous expression system (Ayoub et al., 2002, 2004). By analogy with the $A_{1}-A_{2 A}$ receptor heteromer, those heteromers could be melatonin concentration sensors. The $A_{1}-A_{2 A}$ receptor heteromer senses the extracellular concentration of adenosine to signal via Gs or via Gi. Furthermore, the functionality of $A_{1}-A_{2 A}$ heteroreceptors is mediated by the long $\mathrm{C}$-terminal domain of the $\mathrm{A}_{2 \mathrm{~A}}$ (Navarro et al., 2016, 2018). Existing data do not support a similar role for $\mathrm{MT}_{1}-\mathrm{MT}_{2}$ receptor complexes as the affinity for melatonin is similar (Browning et al., 2000) and the C-terminal domains are similar and not 


\section{Healthy ciliary body cells}

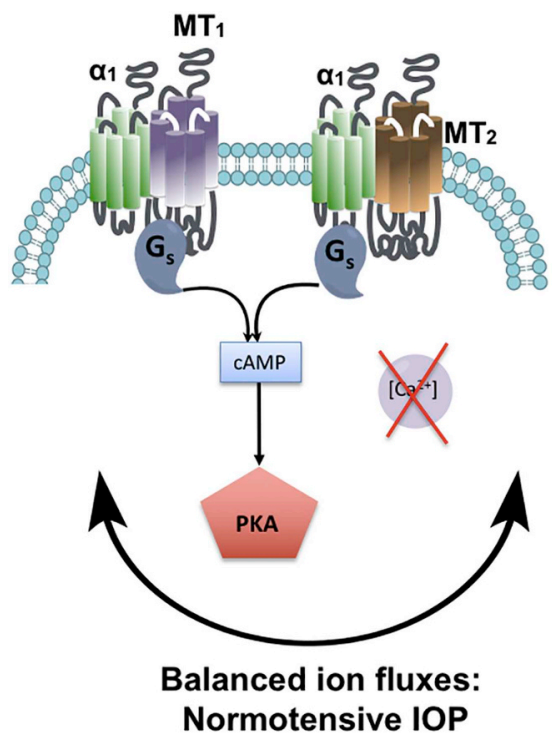

Glaucomatous ciliary body cells

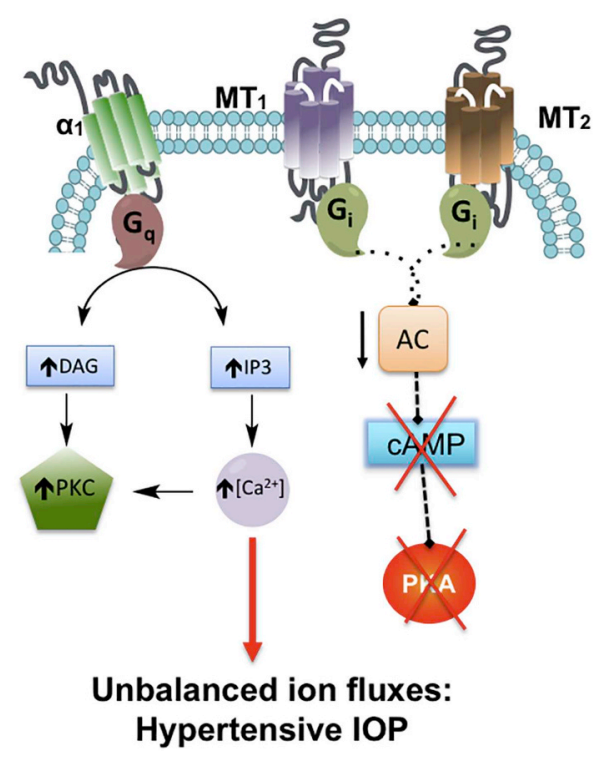

Fig. 9. Signalling via melatonin receptors in ciliary body cells of the normotensive and in the hypertensive eye. In the normotensive eye melatonin receptors form complexes with $\alpha_{1}$-adrenoceptors and these functional units couple to Gs thus leading to increase in cAMP levels, and PKA activity (left). In the hypertensive eye the occurrence of individually expressed $\alpha_{1}$-adrenoceptors allows adrenergic agonists to increase cytosolic $\mathrm{Ca}^{2+}$ levels, and the expression of individual melatonin receptors, which couple to Gi, leads melatonin to decrease cAMP levels and PKA activity (right). particularly long (UNIPROT human sequences: P48039 and P49286). Furthermore, data linking $\mathrm{MT}_{1}-\mathrm{MT}_{2}$ receptor heteromer to modulation of photoreceptor function (Baba et al., 2013) or scotopic T electroretinogram (Piano et al., 2018) are not reliable due to the lack of appropriate controls. There are few tools available to demonstrate heteromer involvement in a given process and all pass by disrupting the heteromer in a very specific manner. Unfortunately, authors used KO animals that do not serve for such purpose (Franco and Franco, 2014). The reason is easy to convey, as a $\mathrm{KO}$ animal for, say the $\mathrm{MT}_{1}$ receptor, will not display any $\mathrm{MT}_{1}$-containing heteromer. Accordingly, any loss of function in the KO can be due to the lack of one, two or several of the heteromers in which $\mathrm{MT}_{1}$ participate. In fact $\mathrm{MT}_{1}$ receptors may interact with other GPCRs such as GPR50 (Levoye et al., 2006), whereas the $\mathrm{MT}_{2}$ receptor may interact with serotonin $5-\mathrm{HT}_{2 \mathrm{C}}$ and with GPR61, GPR62, and GPR135 receptors (Kamal et al., 2015; Oishi et al., 2018).

Although the cognate $\mathrm{G}$ protein coupled to melatonin receptors is Gi, early studies dated back in the nineties showed that receptor activation could also lead to inositol phosphate production thus meaning that Gq coupling was possible (Brydon et al., 1999). The promiscuity in GPCR-G interactions may be an artifact resulting from differential expression of $\mathrm{G}$ proteins in different models and/or different experimental setups but it also may derive from GPCR heteromerization. The latter, if confirmed in natural cells, has enormous physiological relevance in both healthy and diseased conditions. To our knowledge, the first reported shift of coupled $\mathrm{G}$ proteins was reported by the laboratory of Susan George, that showed that dopamine $\mathrm{D}_{1}$ receptors couple to $\mathrm{Gs}, \mathrm{D}_{2}$ receptors couple to $\mathrm{Gi}$ and $\mathrm{D}_{1}-\mathrm{D}_{2}$ receptor heteromer couple to $\mathrm{Gq}$ (Hasbi et al., 2009, 2010; Rashid et al., 2007). In the field of melatonin receptors, $\mathrm{Gq}$ activation is possible within the $\mathrm{MT}_{2} / 5-\mathrm{HT}_{2 \mathrm{C}}$ heteromeric context (Kamal et al., 2015). In summary, despite a given receptor has its cognate $\mathrm{G}$ protein, different $\mathrm{G}$ proteins may be activated when the receptor is forming part of a heteroreceptor functional unit. It is tempting to speculate that melatonin may engage $\mathrm{Gi}$, Gq or Gs depending on the heteromer expressed in the target cell. In fact, apart from the above-described examples of Gi and Gq coupling, Gs coupling was reliably demonstrated by (Huete-Toral et al., 2015) in non-pigmented ciliary epithelial cells. What is important is the link between melatonin-induced cAMP production and the regulation of chloride channels as this mechanism may be involved in the eye pressure lowering capability of the natural indoleamine (Alkozi et al., 2019). The mechanism involves $\mathrm{MT}_{1} / \mathrm{MT}_{2}$-receptor-containing heteromers, which appear altered in the human glaucomatous eye. As earlier commented, adrenoceptors are key in eye physiology. Remarkably, an adrenergic agonist, phenylephrine, did not produce $\mathrm{Ca}^{2+}$ responses in cells expressing either $\alpha_{1 \mathrm{~A}}$ adrenergic-MT $\mathrm{MT}_{1}$ receptor heteromers or $\alpha_{1 \mathrm{~A}}$ adrenergic- $\mathrm{MT}_{2}$ receptor heteromers, despite the fact that $\mathrm{Gq}$ is the cognate protein of this specific adrenoceptor. Such uncoupling seems beneficial, i.e. the lack of adrenergic-induced calcium-mediated events is what is happening in the healthy eye. On the other hand, these $\alpha_{1 \mathrm{~A}}$ receptorcontaining heteromeric complexes couple to Gs and, therefore, receptor activation contributes, via cAMP and PKA activation, to keep IOP within reference values (in the healthy eye). It turns out, that in the ciliary body of the glaucomatous eye, both in animal models and in samples from "real" cases (glaucoma patient eyes) expresses few functional adrenergic-melatonin heteroreceptor units and the altered signalling mediated by individual receptors, especially by $\mathrm{G}_{\mathrm{q}}$-coupled $\alpha_{1 \mathrm{~A}}$ adrenoceptors, negatively impacts on IOP due to significant increases in cytosolic $\left[\mathrm{Ca}^{2+}\right]$. The concomitant increase in calcium ion and the decrease in cAMP in ciliary body cells correlate with increased IOP likely due to altered chloride channel activity both by hydrostatic causes and by imbalance in the PKA-mediated regulation. These findings have led to propose a combination therapy consisting of melatonin and prazosin, an $\alpha_{1 \mathrm{~A}}$ adrenoceptor antagonist that, tested in animal models, have provided spectacular results. Prazosin, not only enhanced melatonin hypotensive action (to $9.0 \pm 0.5 \mathrm{mmHg}$ ) but its effect lasted more than $6 \mathrm{~h}$, thus indicating a very appropriate therapeutic time window (Alkozi et al., 2019). The summary of events taking into account these findings is displayed in Fig. 9. Adrenergic-melatonin heteroreceptor complexes are key in controlling IOP in the normotensive eye; its disruption in glaucoma contributes to the disease but, importantly, offer a new therapeutic avenue that has been successfully tested in glaucoma models. Since prazosin is approved for human therapy and melatonin is safe (even available for oral consumption without being subjected to specific FDA regulations), a combined melatonin-prazosin topical intervention (eye drops) could readily enter into clinical trials to test efficacy in glaucoma.

\section{Future development}

Among the different sides to look at eye-melatonin relationships, there are two we would like to highlight, namely the expression of melatonin-related proteins in the different structures of the eye and the 
identification of the mode of action of melatonin in lowering the IOP in both the healthy and the glaucomatous eye.

To get insight into the reason why melatonin application to the hypertensive eye results in reduced tension despite the levels of the indoleamine are already markedly elevated, it is needed to know whether compartmentalization provides good answers. As it is not possible to identify where melatonin is located, indirect evidence could come from measuring the expression of the mRNAs of synthesizing enzymes in the different ocular structures. In our opinion the use of a technical development that has been recently improved and made easily available would provide the required information at the cell level. The RNAscope ${ }^{\circledR}$-based methodology allows measuring the level of mRNA in tissue sections at the single-cell level (Wang et al., 2012). Therefore, it is now possible to assess the expression of melatoninsynthesizing enzymes simultaneously in all cell types and in all ocular structures. This possibility of direct comparison in the same sample and same conditions (for instance in samples taken at daylight or at night) would accelerate discovery of melatonin actions in the different cells and how they may vary due to circadian rhythms. In parallel, it would be extremely relevant to use the same approach to measure the expression of proteins mediating the action of melatonin, including but not restricted to $\mathrm{MT}_{1}$ and $\mathrm{MT}_{2}$ receptors.

As elsewhere described, the actions of cell surface receptors are complex, specially in what concerns the link between early events and distal actions affecting transcription regulation (Navarro et al., 2017). Furthermore, melatonin has two canonical cell surface GPCRs $\left(\mathrm{MT}_{1}\right.$ and $\mathrm{MT}_{2}$ ) but other potential targets that might not be GPCRs. Melatonin is indeed a pleiotropic molecule (Hardeland, 2009). The actions of melatonin on gene transcription may be indirect although they were first described as reflecting direct interaction with nuclear receptors. A recent review shows the relevance of sirtuin involvement, which leads to deacetylation of poly ADP ribose polymerase- $\gamma$ coactivator-1 $\alpha$ (PGC$1 \alpha)$ and facilitation of retinoic acid receptor-related orphan receptor- $\alpha$ binding to its response element; this mechanism may result from melatonin receptor activation or be mediated by other players (Hardeland, 2018). In summary, the mode of action of melatonin may be heterogeneous with some effects mediated by cell surface receptors and some effects mediated by other targets. Accordingly revisiting the huge amount of melatonin-related data may provide some information on GPCR-independent effects. In addition, it is worth considering some possibilities for GPCRs that have not been explored in full for $\mathrm{MT}_{1}$ and $\mathrm{MT}_{2}$ receptors. In fact, GPCRs may form heteromers and melatonin receptor lack behind others such as adenosine or dopamine receptors (Hasbi et al., 2009, 2010; Hinz et al., 2018; Rashid et al., 2007) in looking for partners and differential signalling. Reliable data showing coupling to G proteins other than Gi should not be neglected. Apart from those above commented, there are quite a number of potential interactions with receptors that are highly expressed in the eye; worth testing potential interactions with other adrenoceptors, with dopamine receptors and with melacortin receptors. The relevant finding would not be the interaction per se but the possibility of differential $\mathrm{G}$ protein coupling and differential signalling thus providing the mechanistic basis of particular modes of action of melatonin depending on the cell type and on the physiopathological condition.

\section{Author statement}

HAA and GN: contributed in writing the manuscript, RF and JP: designed the review, analyzed the data provided and contributed to writing the manuscript.

\section{Funding}

This work was supported by grants from Ministerio de Economía y Competitividad (SAF2013-44416-R) and (SAF2016-77084R), and Ministerio de Sanidad RETICS (RD12/0034/0003) and (RD16/0008/
0017).

\section{Declaration of competing interest}

Authors declare no conflict of interests.

\section{Acknowledgements}

Our first acknowledgement must be to Prof. Jesus Jerónimo (Suso) Pintor, co-author of the paper who passed away in April 2019. He was a model for both colleagues and students; he was nice, he was kind, he was patient; he was enthusiastic; he was a good person. It is our solid opinion that he was the one on Earth who knew more on melatonin in the eye. By reporting what he reliably/reproducibly observed, current dogmas were challenged and he, again, was patient in receiving criticisms and paper rejections. He was a superb scientist and a model to follow. We miss you Suso.

\section{References}

Abe, M., Reiter, R.J., Orhii, P.B., Hara, M., Poeggeler, B., 1994. Inhibitory effect of melatonin on cataract formation in newborn rats: evidence for an antioxidative role for melatonin. J. Pineal Res. 17, 94-100.

Abe, M., Itoh, M.T., Miyata, M., Ishikawa, S., Sumi, Y., 1999. Detection of melatonin, its precursors and related enzyme activities in rabbit lens. Exp. Eye Res. 68, 255-262.

Acuña-Castroviejo, D., Escames, G., Venegas, C., Diaz-Casado, M.E., Lima-Cabello, E., Lopez, L.C., Rosales-Corral, S., Tan, D.X., Reiter, R.J., 2014. Extrapineal melatonin: sources, regulation, and potential functions. Cell. Mol. Life Sci. 71, 2997-3025.

Adler, F.H., 1933. Is the aqueous humor a dialysate? Trans. Am. Ophthalmol. Soc. 31, $131-142$.

Agnati, L.F., Fuxe, K., Zini, I., Lenzi, P., Hokfelt, T., 1980. Aspects on receptor regulation and isoreceptor identification. Med. Biol. 58, 182-187.

Agnati, L.F., Ferre, S., Lluis, C., Franco, R., Fuxe, K., 2003. Molecular mechanisms and therapeutical implications of intramembrane receptor/receptor interactions among heptahelical receptors with examples from the striatopallidal GABA neurons. Pharmacol. Rev. 55, 509-550.

Ahmed, R., Mahavadi, S., Al-Shboul, O., Bhattacharya, S., Grider, J.R., Murthy, K.S., 2013. Characterization of signaling pathways coupled to melatonin receptors in gastrointestinal smooth muscle. Regul. Pept. 184, 96-103.

al-Qassab, H., Cleeves, L.A., Francis, P.L., al-Sereiti, M.R., Findley, L., Hedges, A., Silman, R., Turner, P., 1988. Is there a central nervous withdrawal syndrome associated with discontinuing long-term treatment with propranolol? Hum. Toxicol. 7, 249-254.

Alarma-Estrany, P., Crooke, A., Peral, A., Pintor, J., 2007. Requirement of intact sympathetic transmission for the ocular hypotensive effects of melatonin and 5-MCANAT. Auton. Neurosci. 137, 63-66.

Alkozi, H.A., Pintor, J., 2015. TRPV4 activation triggers the release of melatonin from human non-pigmented ciliary epithelial cells. Exp. Eye Res. 136, 34-37.

Alkozi, H., Sanchez-Naves, J., de Lara, M.J., Carracedo, G., Fonseca, B., Martinez-Aguila, A., Pintor, J., 2017a. Elevated intraocular pressure increases melatonin levels in the aqueous humour. Acta Ophthalmol. 95, e185-e189.

Alkozi, H.A., Perez de Lara, M.J., Pintor, J., 2017b. Melatonin synthesis in the human ciliary body triggered by TRPV4 activation: involvement of AANAT phosphorylation. Exp. Eye Res. 162, 1-8.

Alkozi, H.A., Perez de Lara, M.J., Sanchez-Naves, J., Pintor, J., 2017c. TRPV4 stimulation induced melatonin secretion by increasing arylalkymine $\mathrm{N}$-acetyltransferase (AANAT) protein level. Int. J. Mol. Sci. 18.

Alkozi, H.A., Wang, X., Perez de Lara, M.J., Pintor, J., 2017d. Presence of melanopsin in human crystalline lens epithelial cells and its role in melatonin synthesis. Exp. Eye Res. 154, 168-176.

Alkozi, H.A., Navarro, G., Aguinaga, A., Reyes-Resina, I., Sanchez-Naves, J., Perez de Lara, M.J., Franco, R., Pintor, J., 2019. Adrenergic-melatonin Heteroreceptor Complexes Are Key in Controlling Ion Homeostasis and Intraocular Eye Pressure and Their Disruption Contributes to Hypertensive Glaucoma. https://doi.org/10.1101/ 636688.

Angers, S., Salahpour, A., Joly, E., Hilairet, S., Chelsky, D., Dennis, M., Bouvier, M., 2000. Detection of beta 2-adrenergic receptor dimerization in living cells using bioluminescence resonance energy transfer (BRET). Proc. Natl. Acad. Sci. U. S. A. 97, 3684-3689.

Aptel, F., Weinreb, R.N., Chiquet, C., Mansouri, K., 2016. 24-h monitoring devices and nyctohemeral rhythms of intraocular pressure. Prog. Retin. Eye Res. 55, 108-148.

Axelrod, J., 1974. The pineal gland: a neurochemical transducer. Science 184, $1341-1348$.

Axelrod, J., MacLean, P.D., Albers, R.W., Weissbach, H., 1961. In: Kety, S.S., Elkes, J. (Eds.), Regional Distribution of Methyltransferase Enzymes in the Nervous System and Glandular Tissues. Regional Neurochemistry, Pergamon Press, Oxford, pp. 307-311.

Aydin, E., Sahin, S., 2016. Increased melatonin levels in aqueous humor of patients with proliferative retinopathy in type 2 diabetes mellitus. Int. J. Ophthalmol. 9, 721-724.

Ayoub, M.A., Couturier, C., Lucas-Meunier, E., Angers, S., Fossier, P., Bouvier, M., Jockers, R., 2002. Monitoring of ligand-independent dimerization and ligand-induced 
conformational changes of melatonin receptors in living cells by bioluminescence resonance energy transfer. J. Biol. Chem. 277, 21522-21528.

Ayoub, M.A., Levoye, A., Delagrange, P., Jockers, R., 2004. Preferential formation of MT1/MT2 melatonin receptor heterodimers with distinct ligand interaction proper ties compared with MT2 homodimers. Mol. Pharmacol. 66, 312-321.

Baba, K., Benleulmi-Chaachoua, A., Journe, A.S., Kamal, M., Guillaume, J.L., Dussaud, S., Gbahou, F., Yettou, K., Liu, C., Contreras-Alcantara, S., Jockers, R., Tosini, G., 2013. Heteromeric MT1/MT2 melatonin receptors modulate photoreceptor function. Sci. Signal. 6, ra89.

Baba, K., Davidson, A.J., Tosini, G., 2015. Melatonin entrains PER2::LUC bioluminescence circadian rhythm in the mouse cornea. Investig. Ophthalmol. Vis. Sci. 56, 4753-4758.

Bardak, Y., 2000. Effect of melatonin on lenticular calcium and magnesium in rats exposed to ultraviolet radiation. Ophthalmologica 214, 350-353.

Belforte, N.A., Moreno, M.C., de Zavalia, N., Sande, P.H., Chianelli, M.S., Keller Sarmiento, M.I., Rosenstein, R.E., 2010. Melatonin: a novel neuroprotectant for the treatment of glaucoma. J. Pineal Res. 48, 353-364.

Bergmanson, J.P., 1982. Neural control of intraocular pressure. Am. J. Optom. Physiol Opt. 59, 94-98.

Bernard, M., Donohue, S.J., Klein, D.C., 1995. Human hydroxyindole-O-methyltransferase in pineal gland, retina and Y79 retinoblastoma cells. Brain Res. 696, $37-48$.

Bill, A., 1966. The routes for bulk drainage of aqueous humour in rabbits with and without cyclodialysis. Doc. Ophthalmol. 20, 157-169.

Boland, M.V., Ervin, A.M., Friedman, D.S., Jampel, H.D., Hawkins, B.S., Vollenweider, D., Chelladurai, Y., Ward, D., Suarez-Cuervo, C., Robinson, K.A., 2013. Comparative effectiveness of treatments for open-angle glaucoma: a systematic review for the U.S. Preventive Services Task Force. Ann. Intern. Med. 158, 271-279.

Bonaventura, J., Rico, A.J., Moreno, E., Sierra, S., Sanchez, M., Luquin, N., Farre, D., Muller, C.E., Martinez-Pinilla, E., Cortes, A., Mallol, J., Armentero, M.T., Pinna, A., Canela, E.I., Lluis, C., McCormick, P.J., Lanciego, J.L., Casado, V., Franco, R., 2014. LDOPA-treatment in primates disrupts the expression of $\mathrm{A}(2 \mathrm{~A})$ adenosine- $\mathrm{CB}(1)$ cannabinoid-D(2) dopamine receptor heteromers in the caudate nucleus. Neuropharmacology 79, 90-100.

Borroto-Escuela, D.O., Brito, I., Romero-Fernandez, W., Di Palma, M., Oflijan, J., Skieterska, K., Duchou, J., Van Craenenbroeck, K., Suarez-Boomgaard, D., Rivera, A., Guidolin, D., Agnati, L.F., Fuxe, K., 2014. The G protein-coupled receptor heterodimer network (GPCR-HetNet) and its hub components. Int. J. Mol. Sci. 15, 8570-8590.

Brechue, W.F., Maren, T.H., 1993. A comparison between the effect of topical and systemic carbonic anhydrase inhibitors on aqueous humor secretion. Exp. Eye Res. 57, $67-78$.

Browning, C., Beresford, I., Fraser, N., Giles, H., 2000. Pharmacological characterization of human recombinant melatonin $\mathrm{mt}(1)$ and MT(2) receptors. Br. J. Pharmacol. 129, 877-886.

Brubaker, R.F., 1991. Flow of aqueous humor in humans [The Friedenwald Lecture]. Investig. Ophthalmol. Vis. Sci. 32, 3145-3166.

Brydon, L., Roka, F., Petit, L., de Coppet, P., Tissot, M., Barrett, P., Morgan, P.J., Nanoff, C., Strosberg, A.D., Jockers, R., 1999. Dual signaling of human Mel1a melatonin receptors via G(i2), G(i3), and G(q/11) proteins. Mol. Endocrinol. 13, 2025-2038.

Bubenik, G.A., Brown, G.M., Uhlir, I., Grota, L.J., 1974. Immunohistological localization of $\mathrm{N}$-acetylindolealkylamines in pineal gland, retina and cerebellum. Brain Res. 81, 233-242.

Cahill, G.M., Besharse, J.C., 1995. Circadian rhythmicity in vertebrate retinas: regulation by a photoreceptor oscillator. Prog. Retin. Eye Res. 14, 267-291.

Casson, R.J., Chidlow, G., Ebneter, A., Wood, J.P., Crowston, J., Goldberg, I., 2012 a. Translational neuroprotection research in glaucoma: a review of definitions and principles. Clin. Exp. Ophthalmol. 40, 350-357.

Casson, R.J., Chidlow, G., Wood, J.P., Crowston, J.G., Goldberg, I., 2012b. Definition of glaucoma: clinical and experimental concepts. Clin. Exp. Ophthalmol. 40, 341-349.

Chiou, G.C., 1983. Effects of alpha 1 and alpha 2 activation of adrenergic receptors on aqueous humor dynamics. Life Sci. 32, 1699-1704.

Chiou, G.C., McLaughlin, M.A., 1984. Studies on the involvement of melatonergic mechanism in intraocular pressure regulation. Ophthalmic Res. 16, 302-306.

Civan, M.M., Macknight, A.D., 2004. The ins and outs of aqueous humour secretion. Exp. Eye Res. 78, 625-631.

Coakes, R.L., Brubaker, R.F., 1978. The mechanism of timolol in lowering intraocular pressure. In the normal eye. Arch. Ophthalmol. 96, 2045-2048.

Coakes, R.L., Siah, P.B., 1984. Effects of adrenergic drugs on aqueous humour dynamics in the normal human eye. I. Salbutamol. Br. J. Ophthalmol. 68, 393-397.

Coca-Prados, M., Escribano, J., 2007. New perspectives in aqueous humor secretion and in glaucoma: the ciliary body as a multifunctional neuroendocrine gland. Prog. Retin. Eye Res. 26, 239-262.

Colton, T., Ederer, F., 1980. The distribution of intraocular pressures in the general population. Surv. Ophthalmol. 25, 123-129.

Coon, S.L., Mazuruk, K., Bernard, M., Roseboom, P.H., Klein, D.C., Rodriguez, I.R., 1996. The human serotonin $\mathrm{N}$-acetyltransferase (EC 2.3.1.87) gene (AANAT): structure, chromosomal localization, and tissue expression. Genomics 34, 76-84.

Crichton, A.C., Vold, S., Williams, J.M., Hollander, D.A., 2013. Ocular surface tolerability of prostaglandin analogs and prostamides in patients with glaucoma or ocular hypertension. Adv. Ther. 30, 260-270.

Crooke, A., Huete-Toral, F., Martinez-Aguila, A., Martin-Gil, A., Pintor, J., 2012. Involvement of carbonic anhydrases in the ocular hypotensive effect of melatonin analogue 5-MCA-NAT. J. Pineal Res. 52, 265-270.

Crooke, A., Huete-Toral, F., Martinez-Aguila, A., Martin-Gil, A., Pintor, J., 2013. Melatonin and its analog 5-methoxycarbonylamino- $\mathrm{N}$-acetyltryptamine potentiate adrenergic receptor-mediated ocular hypotensive effects in rabbits: significance for combination therapy in glaucoma. J. Pharmacol. Exp. Ther. 346, 138-145.

Crooke, A., Guzman-Aranguez, A., Mediero, A., Alarma-Estrany, P., Carracedo, G., Pelaez, T., Peral, A., Pintor, J., 2015. Effect of melatonin and analogues on corneal wound healing: involvement of Mt2 melatonin receptor. Curr. Eye Res. 40, 56-65.

Danias, J., Podos, S.M., 1999. Comparison of glaucomatous progression between untreated patients with normal-tension glaucoma and patients with therapeutically reduced intraocular pressures. The effectiveness of intraocular pressure reduction in the treatment of normal-tension glaucoma. Am. J. Ophthalmol. 127, 623-625.

Davson, H., Duke-Elder, W.S., Benham, G.H., 1936. The ionic equilibrium between the aqueous humour and blood plasma of cats. Biochem. J. 30, 773-775.

DelMonte, D.W., Kim, T., 2011. Anatomy and physiology of the cornea. J. Cataract Refract. Surg. 37, 588-598.

Delwig, A., Chaney, S.Y., Bertke, A.S., Verweij, J., Quirce, S., Larsen, D.D., Yang, C., Buhr, E., R, V.A.N.G., Gallar, J., Margolis, T., Copenhagen, D.R., 2018. Melanopsin expression in the cornea. Vis. Neurosci. 35, E004.

Diestelhorst, M., Nordmann, J.P., Toris, C.B., 2002. Combined therapy of pilocarpine or latanoprost with timolol versus latanoprost monotherapy. Surv. Ophthalmol. 47 (Suppl. 1), S155-S161.

Djeridane, Y., Touitou, Y., 2001. Melatonin synthesis in the rat harderian gland: age- and time-related effects. Exp. Eye Res. 72, 487-492.

Djeridane, Y., Vivien-Roels, B., Simonneaux, V., Miguez, J.M., Pevet, P., 1998. Evidence for melatonin synthesis in rodent Harderian gland: a dynamic in vitro study. J. Pineal Res. 25, 54-64.

Dortch-Carnes, J., Tosini, G., 2013. Melatonin receptor agonist-induced reduction of SNPreleased nitric oxide and cGMP production in isolated human non-pigmented ciliary epithelial cells. Exp. Eye Res. 107, 1-10.

Drews, J., 1996. Genomic sciences and the medicine of tomorrow. Nat. Biotechnol. 14, 1516-1518.

Dubocovich, M.L., 1983. Melatonin is a potent modulator of dopamine release in the retina. Nature 306, 782-784

Dufourny, L., Levasseur, A., Migaud, M., Callebaut, I., Pontarotti, P., Malpaux, B., Monget, P., 2008. GPR50 is the mammalian ortholog of Mel1c: evidence of rapid evolution in mammals. BMC Evol. Biol. 8, 105.

Ederer, F., Gaasterland, D.A., Dally, L.G., Kim, J., VanVeldhuisen, P.C., Blackwell, B., Prum, B., Shafranov, G., Allen, R.C., Beck, A., Investigators, A., 2004. The Advanced Glaucoma Intervention Study (AGIS): 13. Comparison of treatment outcomes within race: 10-year results. Ophthalmology 111, 651-664.

Ehinger, B., 1966. Distribution of adrenergic nerves in the eye and some related structures in the cat. Acta Physiol. Scand. 66, 123-128.

Ehinger, B., Falck, B., Rosengren, E., 1969. Adrenergic denervation of the eye by unilateral cervical sympathectomy. Albrecht Von Graefes Arch. Klin. Exp. Ophthalmol. 177, 206-211.

Ferre, S., Baler, R., Bouvier, M., Caron, M.G., Devi, L.A., Durroux, T., Fuxe, K., George, S.R., Javitch, J.A., Lohse, M.J., Mackie, K., Milligan, G., Pfleger, K.D., Pin, J.P., Volkow, N.D., Waldhoer, M., Woods, A.S., Franco, R., 2009. Building a new conceptual framework for receptor heteromers. Nat. Chem. Biol. 5, 131-134.

Foster, P.J., Johnson, G.J., 2001. Glaucoma in China: how big is the problem? Br. J. Ophthalmol. 85, 1277-1282.

Foster, P.J., Buhrmann, R., Quigley, H.A., Johnson, G.J., 2002. The definition and classification of glaucoma in prevalence surveys. Br. J. Ophthalmol. 86, 238-242.

Franco, N., Franco, R., 2014. Understanding the added value of g-protein-coupled receptor heteromers. Scientifica (Cairo) 2014, 362937.

Franco, R., Martinez-Pinilla, E., Lanciego, J.L., Navarro, G., 2016. Basic pharmacological and structural evidence for class A G-protein-coupled receptor heteromerization. Front. Pharmacol. 7, 76.

Fujieda, H., Hamadanizadeh, S.A., Wankiewicz, E., Pang, S.F., Brown, G.M., 1999. Expression of $\mathrm{mt} 1$ melatonin receptor in rat retina: evidence for multiple cell targets for melatonin. Neuroscience 93, 793-799.

Fujieda, H., Scher, J., Hamadanizadeh, S.A., Wankiewicz, E., Pang, S.F., Brown, G.M., 2000. Dopaminergic and GABAergic amacrine cells are direct targets of melatonin: immunocytochemical study of $\mathrm{mt1}$ melatonin receptor in Guinea pig retina. Vis. Neurosci. 17, 63-70.

Gallemore, R.P., Hughes, B.A., Miller, S.S., 1997. Retinal pigment epithelial transport mechanisms and their contributions to the electroretinogram. Prog. Retin. Eye Res. $16,509-566$.

Gastel, J.A., Roseboom, P.H., Rinaldi, P.A., Weller, J.L., Klein, D.C., 1998. Melatonin production: proteasomal proteolysis in serotonin $\mathrm{N}$-acetyltransferase regulation. Science 279, 1358-1360.

Gaton, D.D., Sagara, T., Lindsey, J.D., Gabelt, B.T., Kaufman, P.L., Weinreb, R.N., 2001 Increased matrix metalloproteinases 1,2 , and 3 in the monkey uveoscleral outflow pathway after topical prostaglandin F(2 alpha)-isopropyl ester treatment. Arch. Ophthalmol. 119, 1165-1170.

Gines, S., Hillion, J., Torvinen, M., Le Crom, S., Casado, V., Canela, E.I., Rondin, S., Lew, J.Y., Watson, S., Zoli, M., Agnati, L.F., Verniera, P., Lluis, C., Ferre, S., Fuxe, K., Franco, R., 2000. Dopamine D1 and adenosine A1 receptors form functionally interacting heteromeric complexes. Proc. Natl. Acad. Sci. U. S. A. 97, 8606-8611.

Gomes, I., Jordan, B.A., Gupta, A., Trapaidze, N., Nagy, V., Devi, L.A., 2000. Heterodimerization of mu and delta opioid receptors: a role in opiate synergy. J. Neurosci. 20, RC110.

Greenfield, D.S., Liebmann, J.M., Ritch, R., 1997. Brimonidine: a new alpha2-adrenoreceptor agonist for glaucoma treatment. J. Glaucoma 6, 250-258.

Hardeland, R., 2008. Melatonin, hormone of darkness and more: occurrence, control mechanisms, actions and bioactive metabolites. Cell. Mol. Life Sci. 65, 2001-2018.

Hardeland, R., 2009. Melatonin: signaling mechanisms of a pleiotropic agent. Biofactors $35,183-192$.

Hardeland, R, 2018. Melatonin and retinoid orphan receptors: demand for new 
interpretations after their exclusion as nuclear melatonin receptors. Melatonin Res. 1.

Harteneck, C., Reiter, B., 2007. TRP channels activated by extracellular hypo-osmoticity in epithelia. Biochem. Soc. Trans. 35, 91-95.

Hasbi, A., Fan, T., Alijaniaram, M., Nguyen, T., Perreault, M.L., O'Dowd, B.F., George, S.R., 2009. Calcium signaling cascade links dopamine D1-D2 receptor heteromer to striatal BDNF production and neuronal growth. Proc. Natl. Acad. Sci. U. S. A. 106, $21377-21382$.

Hasbi, A., O'Dowd, B.F., George, S.R., 2010. Heteromerization of dopamine D2 receptors with dopamine D1 or D5 receptors generates intracellular calcium signaling by different mechanisms. Curr. Opin. Pharmacol. 10, 93-99.

Hinz, S., Navarro, G., Borroto-Escuela, D., Seibt, B.F., Ammon, Y.C., de Filippo, E., Danish, A., Lacher, S.K., Cervinkova, B., Rafehi, M., Fuxe, K., Schiedel, A.C., Franco, R., Muller, C.E., 2018. Adenosine A2A receptor ligand recognition and signaling is blocked by A2B receptors. Oncotarget 9, 13593-13611.

Ho, A.K., Thomas, T.P., Chik, C.L., Anderson, W.B., Klein, D.C., 1988. Protein kinase C: subcellular redistribution by increased $\mathrm{Ca} 2+$ influx. Evidence that $\mathrm{Ca} 2+$-dependent subcellular redistribution of protein kinase $\mathrm{C}$ is involved in potentiation of betaadrenergic stimulation of pineal cAMP and cGMP by K+ and A23187. J. Biol. Chem. 263, 9292-9297.

Hodapp, E., Kolker, A.E., Kass, M.A., Goldberg, I., Becker, B., Gordon, M., 1981. The effect of topical clonidine on intraocular pressure. Arch. Ophthalmol. 99, 1208-1211.

Hommer, A., 2010. A review of preserved and preservative-free prostaglandin analogues for the treatment of open-angle glaucoma and ocular hypertension. Drugs Today (Barc) 46, 409-416.

Hoyng, P.F., van Beek, L.M., 2000. Pharmacological therapy for glaucoma: a review. Drugs 59, 411-434.

Huang, H., Wang, Z., Weng, S.J., Sun, X.H., Yang, X.L., 2013. Neuromodulatory role of melatonin in retinal information processing. Prog. Retin. Eye Res. 32, 64-87.

Huete-Toral, F., Crooke, A., Martinez-Aguila, A., Pintor, J., 2015. Melatonin receptors trigger cAMP production and inhibit chloride movements in nonpigmented ciliary epithelial cells. J. Pharmacol. Exp. Ther. 352, 119-128.

Ismail, S.A., Mowafi, H.A., 2009. Melatonin provides anxiolysis, enhances analgesia, decreases intraocular pressure, and promotes better operating conditions during cataract surgery under topical anesthesia. Anesth. Analg. 108, 1146-1151.

Iuvone, P.M., Tosini, G., Pozdeyev, N., Haque, R., Klein, D.C., Chaurasia, S.S., 2005. Circadian clocks, clock networks, arylalkylamine N-acetyltransferase, and melatonin in the retina. Prog. Retin. Eye Res. 24, 433-456.

Jo, A.O., Lakk, M., Frye, A.M., Phuong, T.T., Redmon, S.N., Roberts, R., Berkowitz, B.A., Yarishkin, O., Krizaj, D., 2016. Differential volume regulation and calcium signaling in two ciliary body cell types is subserved by TRPV4 channels. Proc. Natl. Acad. Sci. U. S. A. 113, 3885-3890.

Jones, D.H., Martin, H., Madrazo, J., Robinson, K.A., Nielsen, P., Roseboom, P.H., Patel, Y., Howell, S.A., Aitken, A., 1995. Expression and structural analysis of 14-3-3 proteins. J. Mol. Biol. 245, 375-384.

Kamal, M., Gbahou, F., Guillaume, J.L., Daulat, A.M., Benleulmi-Chaachoua, A., Luka, M., Chen, P., Kalbasi Anaraki, D., Baroncini, M., Mannoury la Cour, C., Millan, M.J., Prevot, V., Delagrange, P., Jockers, R., 2015. Convergence of melatonin and serotonin (5-HT) signaling at MT2/5-HT2C receptor heteromers. J. Biol. Chem. 290, $11537-11546$.

Keeler, C.E., 1928. The geotropic reaction of rodless mice in light and in darkness. J. Gen. Physiol. 11, 361-368.

Klein, D.C., 1978. The pineal gland: a model of neuroendocrine regulation. Res. Publ. Assoc. Res. Nerv. Ment. Dis. 56, 303-327.

Klein, D.C., 2007. Arylalkylamine N-acetyltransferase: "the Timezyme". J. Biol. Chem. 282, 4233-4237.

Klein, D.C., Roseboom, P.H., Donohue, S.J., Marrs, B.L., 1992. Evolution of melatonin as a night signal: contribution from a primitive photosynthetic organism. Mol. Cell. Neurosci. 3, 181-183.

Klein, D.C., Coon, S.L., Roseboom, P.H., Weller, J.L., Bernard, M., Gastel, J.A., Zatz, M., Iuvone, P.M., Rodriguez, I.R., Begay, V., Falcon, J., Cahill, G.M., Cassone, V.M., Baler, R., 1997. The melatonin rhythm-generating enzyme: molecular regulation of serotonin N-acetyltransferase in the pineal gland. Recent Prog. Horm. Res. 52, 307-357 discussion 357-308.

Klein, D.C., Ganguly, S., Coon, S., Weller, J.L., Obsil, T., Hickman, A., Dyda, F., 2002. 143-3 Proteins and photoneuroendocrine transduction: role in controlling the daily rhythm in melatonin. Biochem. Soc. Trans. 30, 365-373.

Konowal, A., Morrison, J.C., Brown, S.V., Cooke, D.L., Maguire, L.J., Verdier, D.V., Fraunfelder, F.T., Dennis, R.F., Epstein, R.J., 1999. Irreversible corneal decompensation in patients treated with topical dorzolamide. Am. J. Ophthalmol. 127, 403-406.

Koyanagi, M., Terakita, A., 2008. Gq-coupled rhodopsin subfamily composed of in vertebrate visual pigment and melanopsin. Photochem. Photobiol. 84, 1024-1030.

Krawietz, W., Weinsteiger, M., Pruchniewski, M., Erdmann, E., 1979. Evidence for negative cooperativity among beta-adrenergic receptors in cardiac and lung tissue of Guinea pig. Biochem. Pharmacol. 28, 2999-3007.

Krizaj, D., Ryskamp, D.A., Tian, N., Tezel, G., Mitchell, C.H., Slepak, V.Z., Shestopalov, V.I., 2014. From mechanosensitivity to inflammatory responses: new players in the pathology of glaucoma. Curr. Eye Res. 39, 105-119.

Krupin, T., Wax, M., Moolchandani, J., 1986. Aqueous production. Trans. Ophthalmol. Soc. U. K. 105 (Pt 2), 156-161.

Lai, F.P., Mody, S.M., Yung, L.Y., Kam, J.Y., Pang, C.S., Pang, S.F., Wong, Y.H., 2002. Molecular determinants for the differential coupling of Galpha(16) to the melatonin MT1, MT2 and Xenopus Mel1c receptors. J. Neurochem. 80, 736-745.

Lavoie, J., Rosolen, S.G., Chalier, C., Hebert, M., 2013. Negative impact of melatonin ingestion on the photopic electroretinogram of dogs. Neurosci. Lett. 543, 78-83.

Lee, D.A., 2005. Ocular hypotensive medications for the treatment of glaucoma.
Ophthalmol Clin North Am 18, 529-538.

Lerner, A.B., Case, J.D., 1959. Pigment cell regulatory factors. J. Investig. Dermatol. 32 211-221.

Lerner, A.B., Nordlund, J.J., 1978. Melatonin: clinical pharmacology. J. Neural Transm. Suppl, 339-347.

Lerner, A.B., Case, J.D., Takahashi, Y., 1960. Isolation of melatonin and 5-methoxyindole3-acetic acid from bovine pineal glands. J. Biol. Chem. 235, 1992-1997.

Leske, M.C., 2007. Open-angle glaucoma - an epidemiologic overview. Ophthalmic Epidemiol. 14, 166-172.

Leske, M.C., Hyman, L., Hussein, M., Heijl, A., Bengtsson, B., 1999. Comparison of glaucomatous progression between untreated patients with normal-tension glaucoma and patients with therapeutically reduced intraocular pressures. The effectiveness of intraocular pressure reduction in the treatment of normal-tension glaucoma. Am. J. Ophthalmol. 127, 625-626.

Levoye, A., Dam, J., Ayoub, M.A., Guillaume, J.L., Couturier, C., Delagrange, P., Jockers, R., 2006. The orphan GPR50 receptor specifically inhibits MT1 melatonin receptor function through heterodimerization. EMBO J. 25, 3012-3023.

Leydhecker, W., Akiyama, K., Neumann, H.G., 1958. Intraocular pressure in norma human eyes. Klin Monbl Augenheilkd Augenarztl Fortbild 133, 662-670.

Li, D.Y., Smith, D.G., Hardeland, R., Yang, M.Y., Xu, H.L., Zhang, L., Yin, H.D., Zhu, Q., 2013. Melatonin receptor genes in vertebrates. Int. J. Mol. Sci. 14, 11208-11223.

Liedtke, W.B., 2007. TRPV channels' function in osmo- and mechanotransduction. In: Liedtke, W.B., Heller, S. (Eds.), TRP Ion Channel Function in Sensory Transduction and Cellular Signaling Cascades, Boca Raton (FL).

Limbird, L.E., Meyts, P.D., Lefkowitz, R.J., 1975. Beta-adrenergic receptors: evidence for negative cooperativity. Biochem. Biophys. Res. Commun. 64, 1160-1168.

Liu, T., Borjigin, J., 2005. N-acetyltransferase is not the rate-limiting enzyme of melatonin synthesis at night. J. Pineal Res. 39, 91-96.

Liu, S.A., Zhao, Z.N., Sun, N.N., Han, Y., Chen, J., Fan, Z.G., 2018. Transitions of the understanding and definition of primary glaucoma. Chin Med J (Engl) 131, 2852-2859.

Lledo, V.E., Alkozi, H.A., Pintor, J., 2019. Yellow filter effect on melatonin secretion in the eye: role in IOP regulation. Curr. Eye Res. 1-5.

Ma, X.P., Shen, M.Y., Shen, G.L., Qi, Q.R., Sun, X.H., 2018. Melatonin concentrations in serum of primary glaucoma patients. Int. J. Ophthalmol. 11, 1337-1341.

Mailliet, F., Ferry, G., Vella, F., Thiam, K., Delagrange, P., Boutin, J.A., 2004. Organs from mice deleted for NRH:quinone oxidoreductase 2 are deprived of the melatonin binding site MT3. FEBS Lett. 578, 116-120.

Mamenko, M., Zaika, O., Boukelmoune, N., O'Neil, R.G., Pochynyuk, O., 2015. Deciphering physiological role of the mechanosensitive TRPV4 channel in the distal nephron. Am. J. Physiol. Renal. Physiol. 308, F275-F286.

Marquis, R.E., Whitson, J.T., 2005. Management of glaucoma: focus on pharmacological therapy. Drugs Aging 22, 1-21.

Martin, X.D., Malina, H.Z., Brennan, M.C., Hendrickson, P.H., Lichter, P.R., 1992. The ciliary body-the third organ found to synthesize indoleamines in humans. Eur. J. Ophthalmol. 2, 67-72.

Martinez-Aguila, A., Fonseca, B., Bergua, A., Pintor, J., 2013. Melatonin analogue agomelatine reduces rabbit's intraocular pressure in normotensive and hypertensive conditions. Eur. J. Pharmacol. 701, 213-217.

Martinez-Aguila, A., Fonseca, B., Perez de Lara, M.J., Pintor, J., 2016. Effect of melatonin and 5-methoxycarbonylamino- $\mathrm{N}$-acetyltryptamine on the intraocular pressure of normal and glaucomatous mice. J. Pharmacol. Exp. Ther. 357, 293-299.

McCannel, C.A., Heinrich, S.R., Brubaker, R.F., 1992. Acetazolamide but not timolol lowers aqueous humor flow in sleeping humans. Graefes Arch. Clin. Exp. Ophthalmol. 230, 518-520.

Mincione, F., Scozzafava, A., Supuran, C.T., 2007. The development of topically acting carbonic anhydrase inhibitors as anti-glaucoma agents. Curr. Top. Med. Chem. 7, 849-854.

Minneman, K.P., Iversen, L.L., 1976. Diurnal rhythm in rat pineal cyclic nucleotide phosphodiesterase activity. Nature 260, 59-61.

Mizumoto, K., Gosho, M., Iwaki, M., Zako, M., 2017. Ocular parameters before and after steep Trendelenburg positioning for robotic-assisted laparoscopic radical prostatectomy. Clin. Ophthalmol. 11, 1643-1650.

Mody, S.M., Ho, M.K., Joshi, S.A., Wong, Y.H., 2000. Incorporation of Galpha(z)-specific sequence at the carboxyl terminus increases the promiscuity of galpha(16) toward G(i)-coupled receptors. Mol. Pharmacol. 57, 13-23.

Moore, R.Y., Klein, D.C., 1974. Visual pathways and the central neural control of a circadian rhythm in pineal serotonin $\mathrm{N}$-acetyltransferase activity. Brain Res. 71, 17-33.

Morgan, P.J., Lawson, W., Davidson, G., Howell, H.E., 1989. Guanine nucleotides regulate the affinity of melatonin receptors on the ovine pars tuberalis. Neuroendocrinology 50, 359-362.

Muslin, A.J., Tanner, J.W., Allen, P.M., Shaw, A.S., 1996. Interaction of 14-3-3 with signaling proteins is mediated by the recognition of phosphoserine. Cell 84, 889-897.

Nagle, C.A., Cardinali, D.P., Rosner, J.M., 1973. Retinal and pineal hydroxyindole-Omethyl transferases in the rat: changes following cervical sympathectomy, pinealectomy or blinding. Endocrinology 92, 1560-1564.

Navarro, G., Cordomi, A., Zelman-Femiak, M., Brugarolas, M., Moreno, E., Aguinaga, D., Perez-Benito, L., Cortes, A., Casado, V., Mallol, J., Canela, E.I., Lluis, C., Pardo, L., Garcia-Saez, A.J., McCormick, P.J., Franco, R. 2016. Quaternary structure of a Gprotein-coupled receptor heterotetramer in complex with Gi and Gs. BMC Biol. $14,26$.

Navarro, G., Franco, N., Martinez-Pinilla, E., Franco, R., 2017. The epigenetic cytocrin pathway to the nucleus. Epigenetic factors, epigenetic mediators, and epigenetic traits. A biochemist perspective. Front. Genet. 8, 179.

Navarro, G., Cordomi, A., Brugarolas, M., Moreno, E., Aguinaga, D., Perez-Benito, L., Ferre, S., Cortes, A., Casado, V., Mallol, J., Canela, E.I., Lluis, C., Pardo, L., 
McCormick, P.J., Franco, R., 2018. Cross-communication between Gi and Gs in a Gprotein-coupled receptor heterotetramer guided by a receptor C-terminal domain. BMC Biol. 16, 24.

Nickla, D.L., Wildsoet, C., Wallman, J., 1998. Visual influences on diurnal rhythms in ocular length and choroidal thickness in chick eyes. Exp. Eye Res. 66, 163-181.

Nickla, D.L., Rada, J.A., Wallman, J., 1999. Isolated chick sclera shows a circadian rhythm in proteoglycan synthesis perhaps associated with the rhythm in ocular elongation. J. Comp. Physiol. 185, 81-90.

Nomura, T., Smelser, G.K., 1974. The identification of adrenergic and cholinergic nerve endings in the trabecular meshwork. Investig. Ophthalmol. 13, 525-532.

Oishi, A., Cecon, E., Jockers, R., 2018. Melatonin receptor signaling: impact of receptor oligomerization on receptor function. Int Rev Cell Mol Biol 338, 59-77.

Osborne, N.N., 1994. Serotonin and melatonin in the iris/ciliary processes and their involvement in intraocular pressure. Acta Neurobiol. Exp. 54 (Suppl. 1), 57-64.

Osborne, N.N., Chidlow, G., 1994. The presence of functional melatonin receptors in the iris-ciliary processes of the rabbit eye. Exp. Eye Res. 59, 3-9.

Pan, Y., Varma, R., 2011. Natural history of glaucoma. Indian J. Ophthalmol. 59 (Suppl. 1) S19-23.

Pearson, R.B., Kemp, B.E., 1991. Protein kinase phosphorylation site sequences and consensus specificity motifs: tabulations. Methods Enzymol. 200, 62-81.

Perez de Lara, M.J., Santano, C., Guzman-Aranguez, A., Valiente-Soriano, F.J., AvilesTrigueros, M., Vidal-Sanz, M., de la Villa, P., Pintor, J., 2014. Assessment of inner retina dysfunction and progressive ganglion cell loss in a mouse model of glaucoma. Exp. Eye Res. 122, 40-49.

Pescosolido, N., Gatto, V., Stefanucci, A., Rusciano, D., 2015. Oral treatment with the melatonin agonist agomelatine lowers the intraocular pressure of glaucoma patients. Ophthalmic Physiol. Opt. 35, 201-205.

Petit, L., Guardiola, B., Delagrange, P., Jockers, R., Strosberg, A.D., 1998. [Signaling by melatonin receptors]. Therapie 53, 421-428.

Pevet, P., 2002. Melatonin. Dialogues Clin. Neurosci. 4, 57-72.

Pevet, P., 2014. The internal time-giver role of melatonin. A key for our health. Rev. Neurol. (Paris) 170, 646-652.

Piano, I., Baba, K., Claudia, G., Tosini, G., 2018. Heteromeric MT1/MT2 melatonin receptors modulate the scotopic electroretinogram via PKCzeta in mice. Exp. Eye Res. 177, 50-54.

Pierce, M.E., Besharse, J.C., 1985. Circadian regulation of retinomotor movements. I Interaction of melatonin and dopamine in the control of cone length. J. Gen. Physiol. 86, 671-689.

Pinna, A., Bonaventura, J., Farre, D., Sanchez, M., Simola, N., Mallol, J., Lluis, C., Costa, G., Baqi, Y., Muller, C.E., Cortes, A., McCormick, P., Canela, E.I., Martinez-Pinilla, E., Lanciego, J.L., Casado, V., Armentero, M.T., Franco, R., 2014. L-DOPA disrupts adenosine $\mathrm{A}(2 \mathrm{~A})$-cannabinoid $\mathrm{CB}(1)$-dopamine $\mathrm{D}(2)$ receptor heteromer cross-talk in the striatum of hemiparkinsonian rats: biochemical and behavioral studies. Exp. Neurol. 253, 180-191.

Pintor, J., 2018. Pharmacology without drugs. J. Opt. 11, 201-202.

Pintor, J., Martin, L., Pelaez, T., Hoyle, C.H., Peral, A., 2001. Involvement of melatonin MT(3) receptors in the regulation of intraocular pressure in rabbits. Eur. J. Pharmacol. 416, 251-254.

Pintor, J., Pelaez, T., Hoyle, C.H., Peral, A., 2003. Ocular hypotensive effects of melatonin receptor agonists in the rabbit: further evidence for an MT3 receptor. Br. J. Pharmacol. 138, 831-836.

Polo, V., Larrosa, J.M., Gomez, M.L., Pablo, L., Honrubia, F.M., 2001. Latanoprost versus combined therapy with timolol plus dorzolamide: IOP-lowering effect in open-angle glaucoma. Acta Ophthalmol. Scand. 79, 6-9.

Prinster, S.C., Hague, C., Hall, R.A., 2005. Heterodimerization of g protein-coupled receptors: specificity and functional significance. Pharmacol. Rev. 57, 289-298.

Provencio, I., Rodriguez, I.R., Jiang, G., Hayes, W.P., Moreira, E.F., Rollag, M.D., 2000. A novel human opsin in the inner retina. J. Neurosci. 20, 600-605.

Qiu, X., Kumbalasiri, T., Carlson, S.M., Wong, K.Y., Krishna, V., Provencio, I., Berson, D.M., 2005. Induction of photosensitivity by heterologous expression of melanopsin. Nature 433, 745-749.

Quera Salva, M.A., Hartley, S., Leger, D., Dauvilliers, Y.A., 2017. Non-24-Hour sleep-wake rhythm disorder in the totally blind: diagnosis and management. Front. Neurol. 8, 686.

Quigley, H.A., 2011. Glaucoma. Lancet 377, 1367-1377.

Quigley, H.A., Broman, A.T., 2006. The number of people with glaucoma worldwide in 2010 and 2020. Br. J. Ophthalmol. 90, 262-267.

Rada, J.A., Wiechmann, A.F., 2006. Melatonin receptors in chick ocular tissues: implications for a role of melatonin in ocular growth regulation. Investig. Ophthalmol. Vis. Sci. 47, 25-33.

Rashid, A.J., So, C.H., Kong, M.M., Furtak, T., El-Ghundi, M., Cheng, R., O'Dowd, B.F., George, S.R., 2007. D1-D2 dopamine receptor heterooligomers with unique pharmacology are coupled to rapid activation of Gq/11 in the striatum. Proc. Natl. Acad. Sci. U. S. A. 104, 654-659.

Reiter, R.J., 1991. Pineal melatonin: cell biology of its synthesis and of its physiological interactions. Endocr. Rev. 12, 151-180.

Reiter, R.J., Tan, D.X., Galano, A., 2014a. Melatonin: exceeding expectations. Physiology (Bethesda) 29, 325-333.

Reiter, R.J., Tan, D.X., Kim, S.J., Cruz, M.H., 2014b. Delivery of pineal melatonin to the brain and SCN: role of canaliculi, cerebrospinal fluid, tanycytes and Virchow-Robin perivascular spaces. Brain Struct. Funct. 219, 1873-1887.

Reitsamer, H.A., Posey, M., Kiel, J.W., 2006. Effects of a topical alpha2 adrenergic agonist on ciliary blood flow and aqueous production in rabbits. Exp. Eye Res. 82, 405-415.

Remaury, A., Larrouy, D., Daviaud, D., Rouot, B., Paris, H., 1993. Coupling of the alpha 2adrenergic receptor to the inhibitory G-protein Gi and adenylate cyclase in HT29 cells. Biochem. J. 292 (Pt 1), 283-288.
Reppert, S.M., 1997. Melatonin receptors: molecular biology of a new family of G proteincoupled receptors. J. Biol. Rhythm. 12, 528-531.

Reppert, S.M., Weaver, D.R., Ebisawa, T., 1994. Cloning and characterization of a mammalian melatonin receptor that mediates reproductive and circadian responses. Neuron 13, 1177-1185.

Reppert, S.M., Godson, C., Mahle, C.D., Weaver, D.R., Slaugenhaupt, S.A., Gusella, J.F., 1995. Molecular characterization of a second melatonin receptor expressed in human retina and brain: the Mel1b melatonin receptor. Proc. Natl. Acad. Sci. U. S. A. 92, 8734-8738.

Reppert, S.M., Weaver, D.R., Ebisawa, T., Mahle, C.D., Kolakowski Jr., L.F., 1996. Cloning of a melatonin-related receptor from human pituitary. FEBS Lett. 386, 219-224.

Rivara, S., Lorenzi, S., Mor, M., Plazzi, P.V., Spadoni, G., Bedini, A., Tarzia, G., 2005. Analysis of structure-activity relationships for MT2 selective antagonists by melatonin MT1 and MT2 receptor models. J. Med. Chem. 48, 4049-4060.

Sakai, H., Shinjyo, S., Nakamura, Y., Nakamura, Y., Ishikawa, S., Sawaguchi, S., 2005. Comparison of latanoprost monotherapy and combined therapy of $0.5 \%$ timolol and $1 \%$ dorzolamide in chronic primary angle-closure glaucoma (CACG) in Japanese patients. J. Ocul. Pharmacol. Ther. 21, 483-489.

Sakanaka, K., Kawazu, K., Tomonari, M., Kitahara, T., Nakashima, M., Nishida, K., Nakamura, J., Sasaki, H., Higuchi, S., 2008. Ocular pharmacokinetic/pharmacodynamic modeling for multiple anti-glaucoma drugs. Biol. Pharm. Bull. 31, 1590-1595.

Sampaio Lde, F., Mesquita, F.P., de Sousa, P.R., Silva, J.L., Alves, C.N., 2014. The melatonin analog 5-MCA-NAT increases endogenous dopamine levels by binding NRH:quinone reductase enzyme in the developing chick retina. Int. J. Dev. Neurosci. 38, 119-126.

Scher, J., Wankiewicz, E., Brown, G.M., Fujieda, H., 2002. MT(1) melatonin receptor in the human retina: expression and localization. Investig. Ophthalmol. Vis. Sci. 43, 889-897.

Schomerus, C., Korf, H.W., 2005. Mechanisms regulating melatonin synthesis in the mammalian pineal organ. Ann. N. Y. Acad. Sci. 1057, 372-383.

Selbach, J.M., Gottanka, J., Wittmann, M., Lutjen-Drecoll, E., 2000. Efferent and afferent innervation of primate trabecular meshwork and scleral spur. Investig. Ophthalmol. Vis. Sci. 41, 2184-2191.

Serle, J.B., Wang, R.F., Peterson, W.M., Plourde, R., Yerxa, B.R., 2004. Effect of 5-MCANAT, a putative melatonin MT3 receptor agonist, on intraocular pressure in glaucomatous monkey eyes. J. Glaucoma 13, 385-388.

Shi, X.P., Zamudio, A.C., Candia, O.A., Wolosin, J.M., 1996. Adreno-cholinergic modulation of junctional communications between the pigmented and nonpigmented layers of the ciliary body epithelium. Investig. Ophthalmol. Vis. Sci. 37, 1037-1046.

Shiu, S.Y., Pang, B., Tam, C.W., Yao, K.M., 2010. Signal transduction of receptor-mediated antiproliferative action of melatonin on human prostate epithelial cells involves dual activation of Galpha(s) and Galpha(q) proteins. J. Pineal Res. 49, 301-311.

Soderberg, O., Gullberg, M., Jarvius, M., Ridderstrale, K., Leuchowius, K.J., Jarvius, J., Wester, K., Hydbring, P., Bahram, F., Larsson, L.G., Landegren, U., 2006. Direct observation of individual endogenous protein complexes in situ by proximity ligation. Nat. Methods 3, 995-1000.

Sokabe, T., Fukumi-Tominaga, T., Yonemura, S., Mizuno, A., Tominaga, M., 2010. The TRPV4 channel contributes to intercellular junction formation in keratinocytes. J. Biol. Chem. 285, 18749-18758.

Songyang, Z., Lu, K.P., Kwon, Y.T., Tsai, L.H., Filhol, O., Cochet, C., Brickey, D.A., Soderling, T.R., Bartleson, C., Graves, D.J., DeMaggio, A.J., Hoekstra, M.F., Blenis, J., Hunter, T., Cantley, L.C., 1996. A structural basis for substrate specificities of protein Ser/Thr kinases: primary sequence preference of casein kinases I and II, NIMA, phosphorylase kinase, calmodulin-dependent kinase II, CDK5, and Erk1. Mol. Cell. Biol. 16, 6486-6493.

Suofu, Y., Li, W., Jean-Alphonse, F.G., Jia, J., Khattar, N.K., Li, J., Baranov, S.V., Leronni, D., Mihalik, A.C., He, Y., Cecon, E., Wehbi, V.L., Kim, J., Heath, B.E., Baranova, O.V. Wang, X., Gable, M.J., Kretz, E.S., Di Benedetto, G., Lezon, T.R., Ferrando, L.M., Larkin, T.M., Sullivan, M., Yablonska, S., Wang, J., Minnigh, M.B., Guillaumet, G, Suzenet, F., Richardson, R.M., Poloyac, S.M., Stolz, D.B., Jockers, R., Witt-Enderby, P.A., Carlisle, D.L., Vilardaga, J.P., Friedlander, R.M., 2017. Dual role of mitochondria in producing melatonin and driving GPCR signaling to block cytochrome $\mathrm{c}$ release. Proc. Natl. Acad. Sci. U. S. A. 114, E7997-E8006.

Tan, D.X., Manchester, L.C., Reiter, R.J., 2016. CSF generation by pineal gland results in a robust melatonin circadian rhythm in the third ventricle as an unique light/dark signal. Med. Hypotheses 86, 3-9.

Ten Tusscher, M.P., Klooster, J., Baljet, B., Van der Werf, F., Vrensen, G.F., 1990. Pre- and post-ganglionic nerve fibres of the pterygopalatine ganglion and their allocation to the eyeball of rats. Brain Res. 517, 315-323.

Tosini, G., Fukuhara, C., 2003. Photic and circadian regulation of retinal melatonin in mammals. J. Neuroendocrinol. 15, 364-369.

Tslm, S.T., Wong, J.T., Wong, Y.H., 1996. CGP 52608-induced cyst formation in dinoflagellates: possible involvement of a nuclear receptor for melatonin. J. Pineal Res. 21, 101-107.

Turk, A., Ceylan, O.M., Gokce, G., Borazan, M., Kola, M., 2015. Comparison of brimonidine-timolol and dorzolamide-timolol in the management of intraocular pressure increase after phacoemulsi fi cation. Int. J. Ophthalmol. 8, 945-949.

Valdez, D.J., Nieto, P.S., Garbarino-Pico, E., Avalle, L.B., Diaz-Fajreldines, H., Schurrer, C., Cheng, K.M., Guido, M.E., 2009. A nonmammalian vertebrate model of blindness reveals functional photoreceptors in the inner retina. FASEB J. 23, 1186-1195.

Vanecek, J., 1998. Cellular mechanisms of melatonin action. Physiol. Rev. 78, 687-721.

von Gall, C., Weaver, D.R., Kock, M., Korf, H.W., Stehle, J.H., 2000. Melatonin limits transcriptional impact of phosphoCREB in the mouse SCN via the Mel1a receptor. Neuroreport 11, 1803-1807.

von Gall, C., Stehle, J.H., Weaver, D.R., 2002. Mammalian melatonin receptors: molecular biology and signal transduction. Cell Tissue Res. 309, 151-162. 
Wang, F., Flanagan, J., Su, N., Wang, L.C., Bui, S., Nielson, A., Wu, X., Vo, H.T., Ma, X.J., Luo, Y., 2012. RNAscope: a novel in situ RNA analysis platform for formalin-fixed, paraffin-embedded tissues. J. Mol. Diagn. 14, 22-29.

White, M.P., Fisher, L.J., 1989. Effects of exogenous melatonin on circadian disc shedding in the albino rat retina. Vis. Res. 29, 167-179.

Wiechmann, A.F., 2003. Differential distribution of Mel(1a) and Mel(1c) melatonin receptors in Xenopus laevis retina. Exp. Eye Res. 76, 99-106.

Wiechmann, A.F., Rada, J.A., 2003. Melatonin receptor expression in the cornea and sclera. Exp. Eye Res. 77, 219-225.

Wiechmann, A.F., Sherry, D.M., 2012. Melatonin receptors are anatomically organized to modulate transmission specifically to cone pathways in the retina of Xenopus laevis. J. Comp. Neurol. 520, 1115-1127.

Wiechmann, A.F., Sherry, D.M., 2013. Role of melatonin and its receptors in the vertebrate retina. Int Rev Cell Mol Biol 300, 211-242.

Wiechmann, A.F., Summers, J.A., 2008. Circadian rhythms in the eye: the physiological significance of melatonin receptors in ocular tissues. Prog. Retin. Eye Res. 27, 137-160.
Wiechmann, A.F., Udin, S.B., Summers Rada, J.A., 2004. Localization of Mel1b melatonin receptor-like immunoreactivity in ocular tissues of Xenopus laevis. Exp. Eye Res. 79, 585-594.

Wurtman, R.J., Axelrod, J., Phillips, L.S., 1963. Melatonin synthesis in the pineal gland: control by light. Science 142, 1071-1073.

Zachariou, V., Duman, R.S., Nestler, E.J., 2012. G protein. In: Brady, S.T., Albers, R.W., Siegel, G.J., Price, D.L. (Eds.), Basic Neurochemistry, eighth ed. Elsevier Inc., pp. $411-422$.

Zawilska, J.B., 1992. Melatonin in vertebrate retina: biosynthesis, receptors and functions. Pol. J. Pharmacol. Pharm. 44, 627-654.

Zawilska, J.B., Rosiak, J., Vivien-Roels, B., Skene, D.J., Pevet, P., Nowak, J.Z., 2002. Daily variation in the concentration of 5-methoxytryptophol and melatonin in the duck pineal gland and plasma. J. Pineal Res. 32, 214-218.

Zmijewski, M.A., Sweatman, T.W., Slominski, A.T., 2009. The melatonin-producing system is fully functional in retinal pigment epithelium (ARPE-19). Mol. Cell. Endocrinol. 307, 211-216. 